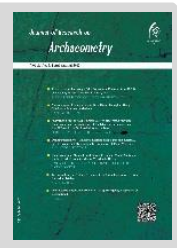

\title{
The Absolute and Relative Chronology of Tepe Crossark Vakilabad: A Reappraisal of the Chronology of the Chalcolithic Period of Tepe Yahya in SE Iran
}

\author{
Mojgan Shafiee $^{1 \star}$, Hekmat Allah Molla Salehi ${ }^{2}$, Nasir Eskandari ${ }^{3}$, Ali Daneshi ${ }^{4}$ \\ ${ }^{1}$ Ph.D. Candidate, University of Tehran and Lyon II, Tehran, IRAN \\ ${ }^{2}$ Professor, Department of Archaeology, University of Tehran, Tehran, IRAN \\ ${ }^{3}$ Assistant Professor, Department of Archaeology, University of Jiroft, Jiroft, IRAN \\ ${ }^{4}$ Expert of Cultural Heritage of Kerman province, Kerman, IRAN
}

Received: 20/03/2019

Accepted: 25/06/2019

\begin{abstract}
After half a century, a new excavation project was launched in Orzu'iyeh (Soghan valley), southeastern Iran where the well-published Tepe Yahya is located. Tepe Yahya was discovered in 1967 by a survey team from Harvard University under the direction of C.C. Lamberg-Karlovsky. It was occupied, with interruptions, from the late Neolithic to the early Sasanian period. Indeed, Tepe Yahya remains the main controlled excavation carried out to date within south east Iran. According to the cultural sequence of Tepe Yahya, periods VI and V appeared to be the Chalcolithic levels of the site ( $6^{\text {th }}-4^{\text {th }}$ Millennium BC). This paper intends to present the results of a new excavation project in this area. Due to the exciting discovery of major Bronze Age urban centers in south-eastern Iran, such as Shahr e Sukhteh (Sistan), Shahdad and Konar Sandal (Jiroft), most scholarly attention has been given to the $3^{\text {rd }}$ millennium $\mathrm{BC}$. As a result, the cultures preceding the Bronze Age have been often neglected, whereas the Bronze Age cultures had developed from the Chalcolithic ones. Tepe Vakilabad, as a Chalcolithic key site in the south-eastern Iran, would help us to recognize better the cultures of this era. This mound is located in the Orzu'iyeh district in the south west of Kerman province, south-eastern Iran. The area of Orzu'iyeh is known in the archeology of Iran due to the presence of Tepe Yahya and also to its strategic location. This area is a natural corridor drawn in the east-west direction connecting south of Kerman province to Fars. The eastern part of this plain includes Soghun Valley (where Tepe Yahya is situated), and the middle and western parts are respectively Dowlatabad and Vakilabad plains. This mound contains more than 4 meters of cultural layers belonging to the chalcolithic periods which reveal how important this site could be, but unfortunately, it is badly damaged and bulldozed. This paper states the results of the stratigraphy excavation of Tepe Vakilabad, where a total of 6 C-14 radiocarbon charcoal samples were collected from the only trench of this mound and analyzed by the Accelerator Mass Spectrometer (AMS) method in the laboratory of university of Lyon, France. Since the chronology of south-eastern Iran is based on the old and not very precise results of Tepe Yahya and Tal-Iblis excavations, it needs the revision. The main objective of this study was to go through the chronology table of south-eastern Iran and discuss it critically with the aid of Vakilabad and the other recent excavations results of the region, such as Tepe Dehno Shahdad. According to a comparative analysis based on the ceramics of this excavated settlement site, it could be concluded that Vakilabad belongs to Yahya V culture, and based on the absolute dating results (mostly ceramics), this site dates back to the early fifth
\end{abstract}

*Corresponding author: shafie.mozhgan@yahoo.com 
millennium BC to the mid-fifth millennium BC. Finally, the Chalcolithic cultures of the southern Iran will be discussed in a broader context of Near East. It is obvious that the reappraisal of the chronology of this vast cultural region needs further studies, where the present paper may be able to collaborate in these researches.

Keywords: Tepe Vakilabad, Orzu'iyeh, Tepe Yahya, Absolute Dating, AMS 


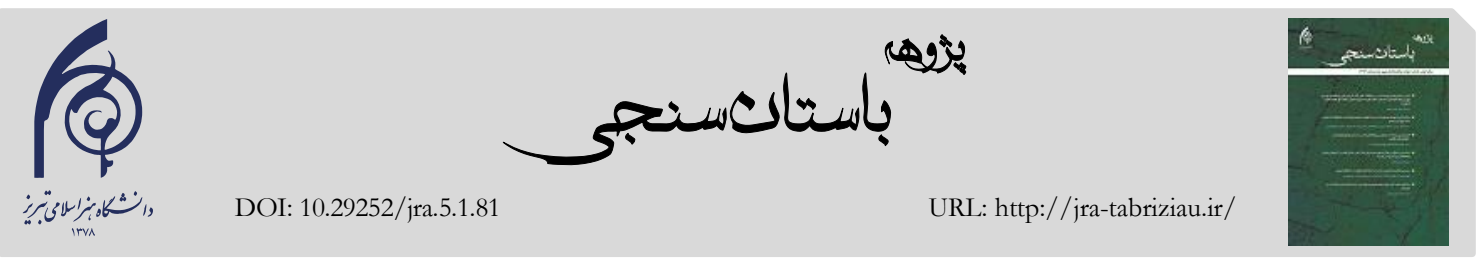

sân

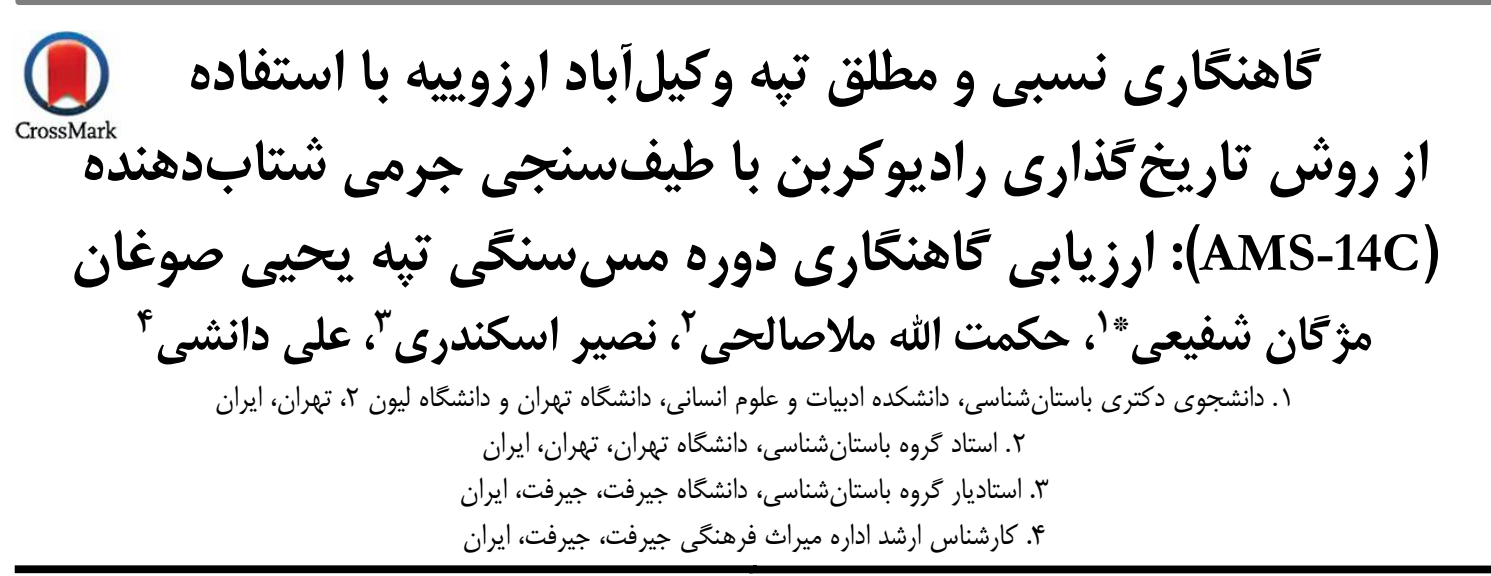

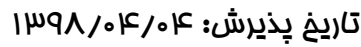

Iس تاريخ دريافت:

جִكيده

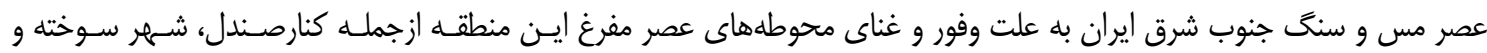

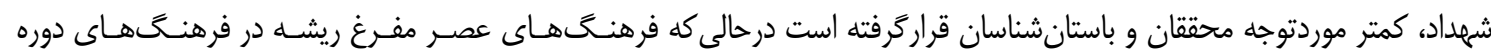

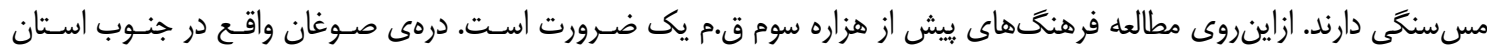

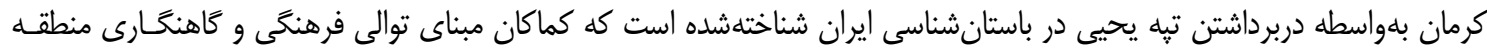

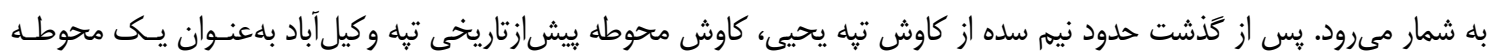

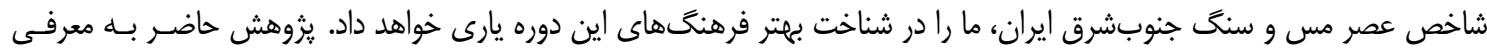

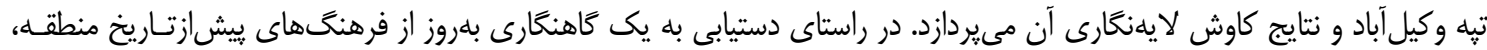

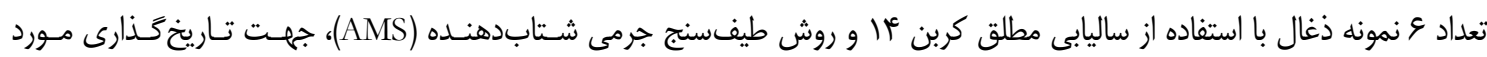

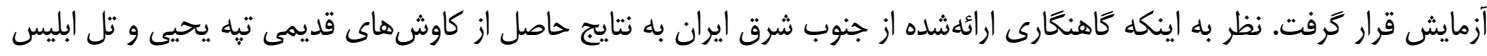

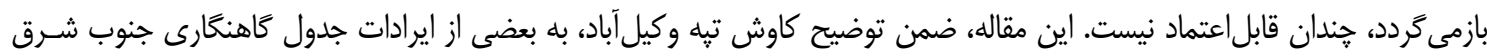

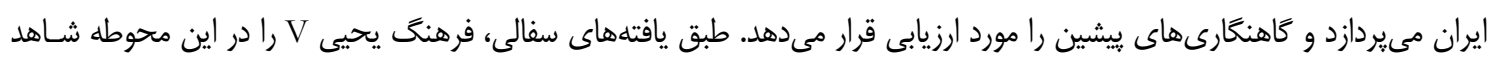

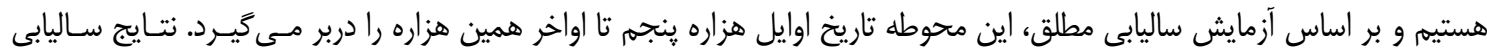

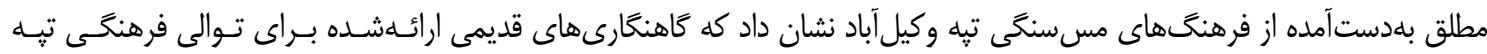

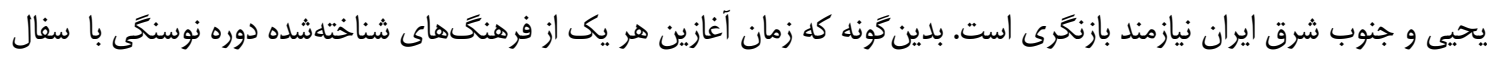

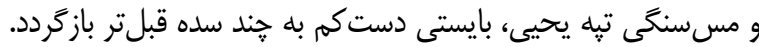

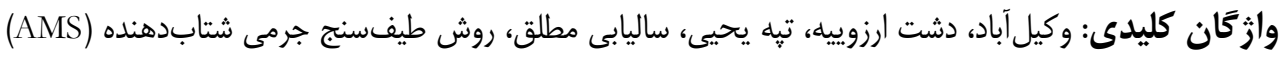

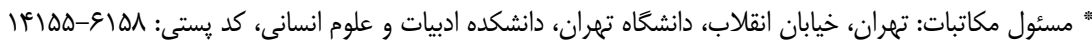

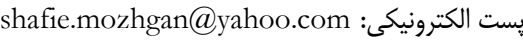
حق نشر متعلق به نويسنده(گان) است و نويسنده تحت مجوز Creative Commons Attribution License به مجله اجازه مى دهد مقاله خاب شده را با ديخران به اشتراك بخذارد منوط بر اينكه حقوق مؤلف اثر حفظ و به انتشار اوليه مقاله در اين مجله اشاره شود. 
جنـوب مينـاب، محـلهــاى مربـوط بــه دوران VA در

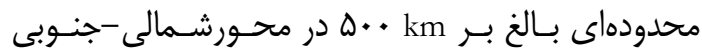

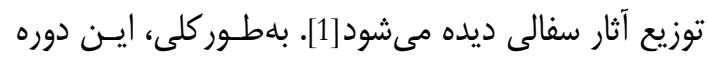

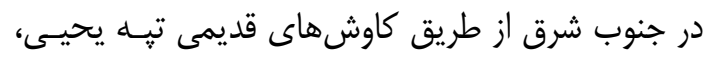

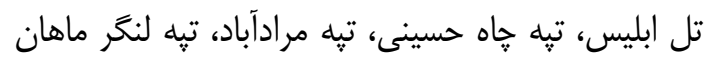

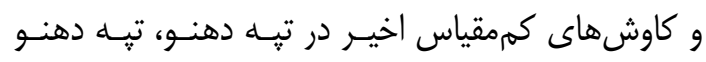

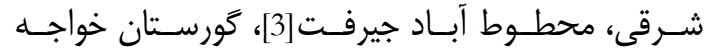

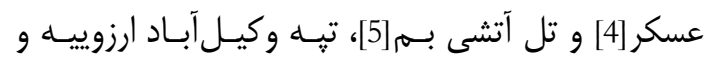

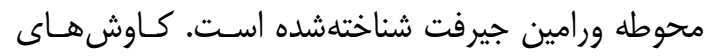

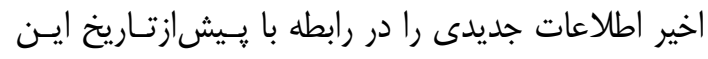

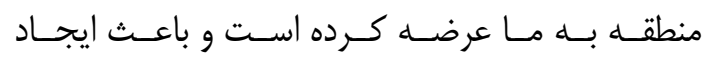

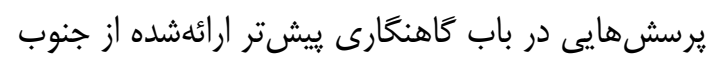
شرق ايران شده است.

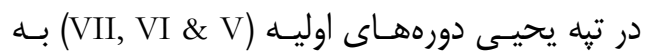

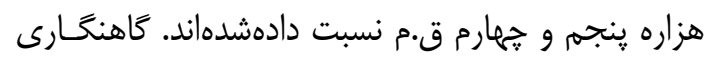

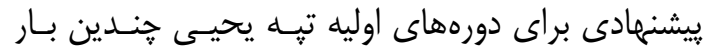

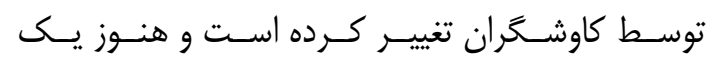

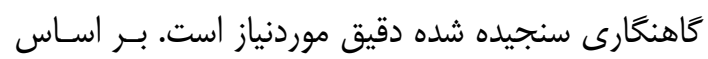

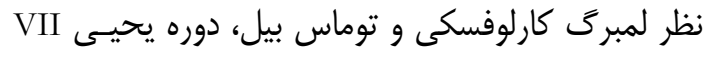

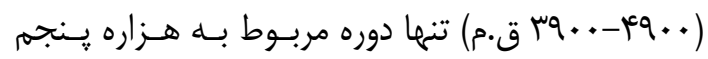

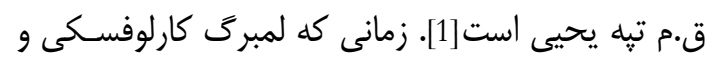

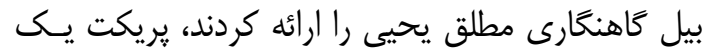
تاريخ بازسنجى شده براى دورههـاى اوليـه يحيـى ارائسه

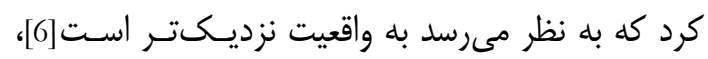

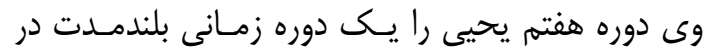

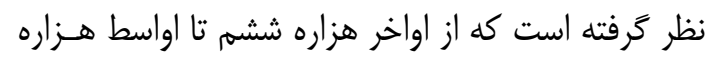

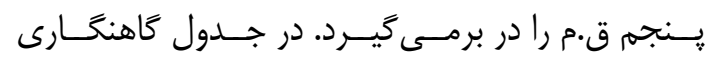

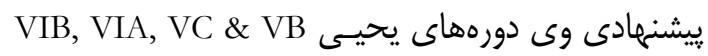
در يك گروه جاى داده شدهاند و يكى دوره زمـانى كوتـاه

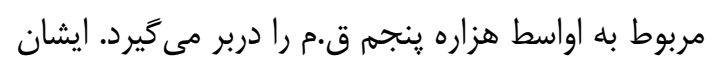

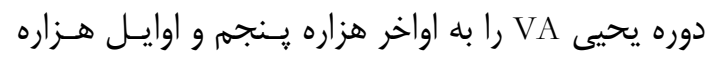

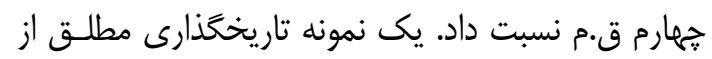

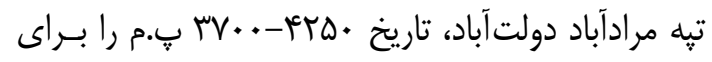
دوره يحيى VA نشان مىدهد. درمجموع، بريكت تـاريخ

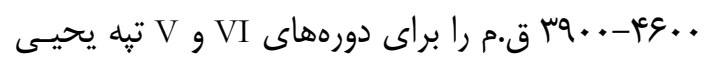

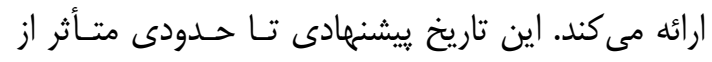

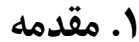

دشـت ارزوييـهـ بــهواســطه موقعيـت راهبـردىاش، در

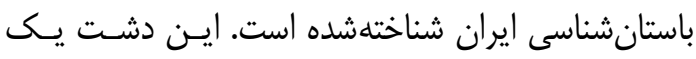
كريدور طبيعى است كه در جهت شـرقى غربسى كشـيده

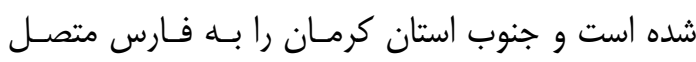
مى كند. بخش شرقى دشت ارزوييه شامل دشت صوغان (محل قرارگيرى تيه يحيى)، بخش ميانى و غربى آن به ديه

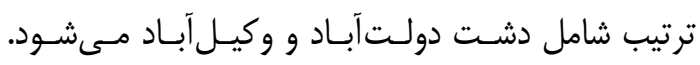
بلاستثناى بررسى هاى يراكنده هيئت باستانشناسى موزه

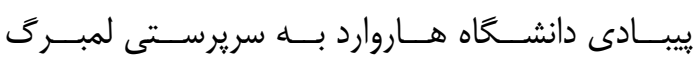
كارلوفسكى[1] و بررسى باستانشناسى شهرستان ارزوييه

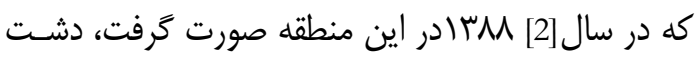
ارزوييه تا به امروز جندان موردمطالعه قرار نخَرفته است.

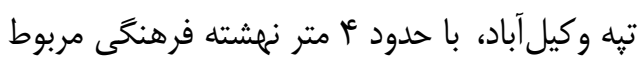

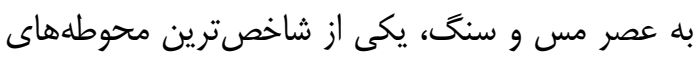

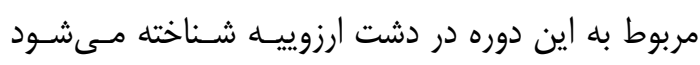

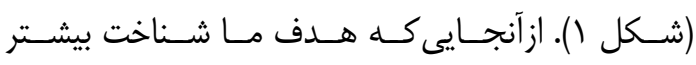

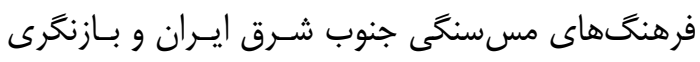

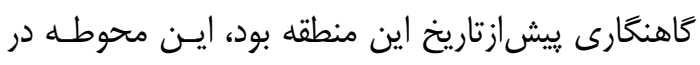

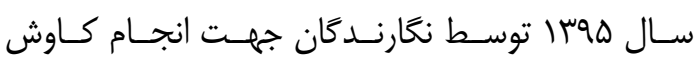
لايهنغارى انتخاب شد. بر اساس آزمايشهـاى سـاليابى

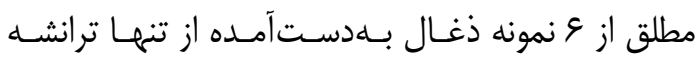
كاوش شده، اين محوطه متعلق به هزاره ينجم ق.م و بر بر بـ

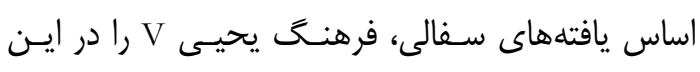
محوطه شاهد هستيه.

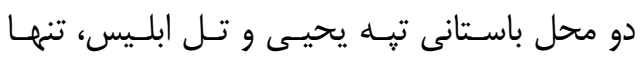

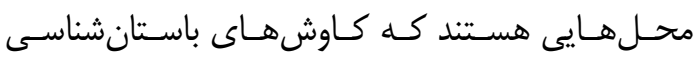

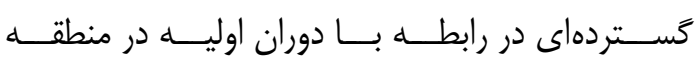

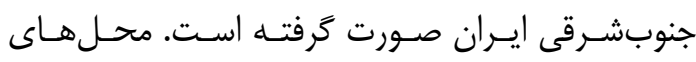

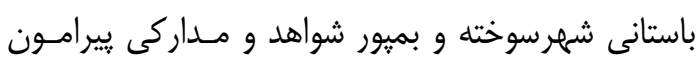

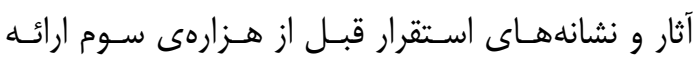

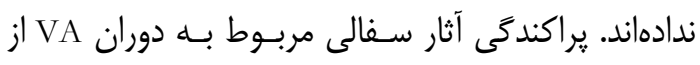
محل باستانى جاهحسينى در قسـمت شـرقى، تـا محـل

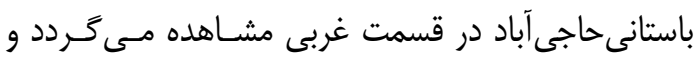

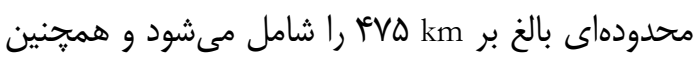

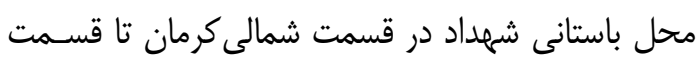




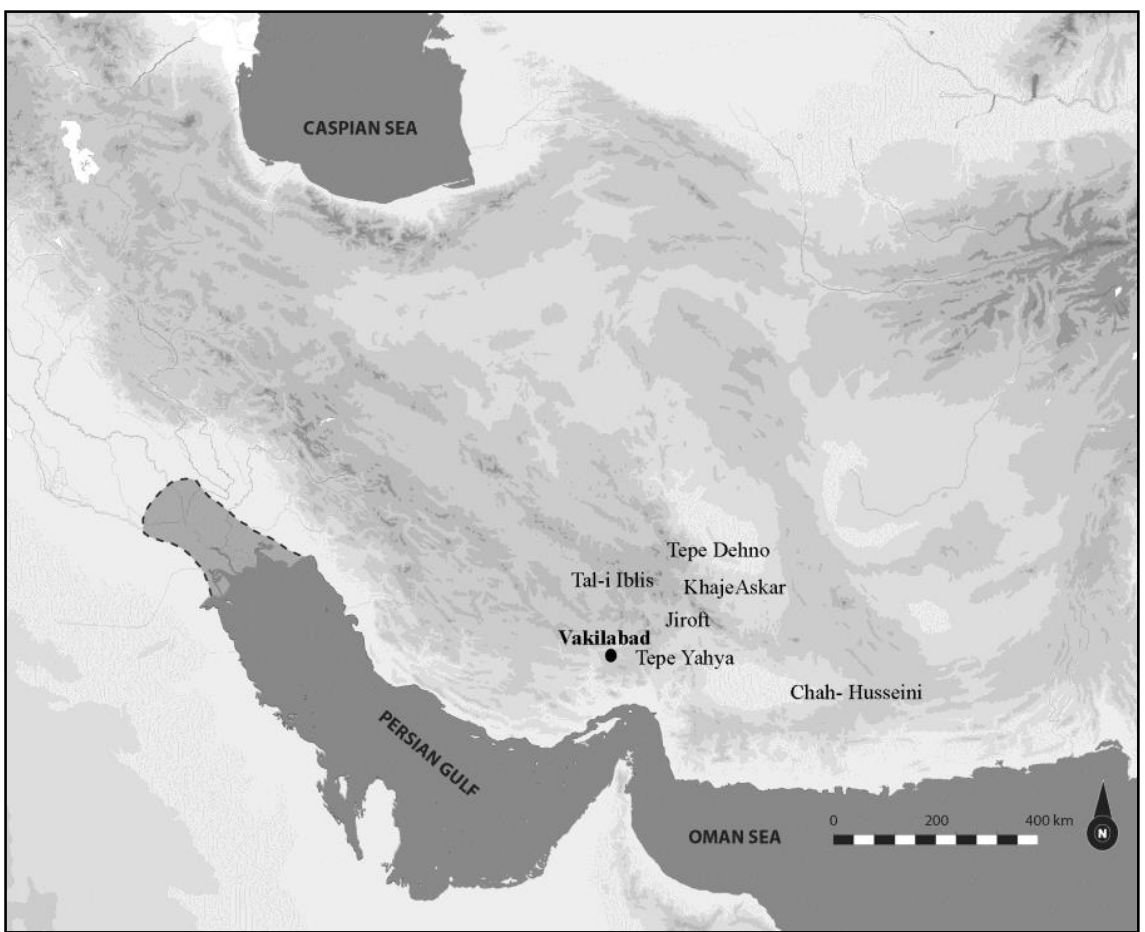

شكل (: نقشه جغرافيايى نشاندهنده موقعيت تِه وكيل آباد و ديخر محوطههاى كاوش شده دوره مسسنكى جنوب شرق ايران Fig.1. The geographical map containing the location of tepe Vakilabad as well as other excavated calcholithic sites in SE Iran

\section{r. بيشينه تحقيق}

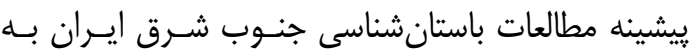

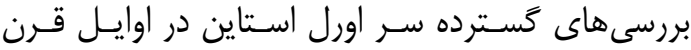
بيستم در اين منطقه بازمى گردد[?]. نخستين كاوشهاى

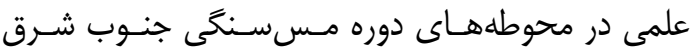

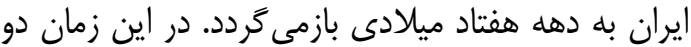

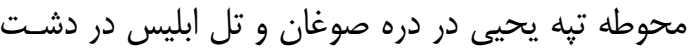

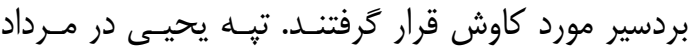

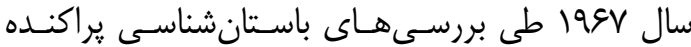

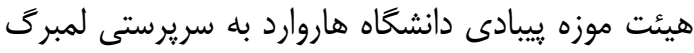

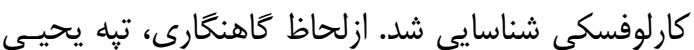

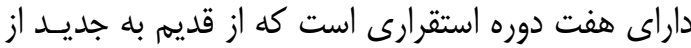
هفت تا يك شمارهذارى شدهاند. قديمى تـرين استقرار

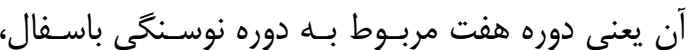
دورههاى شش و ينج توالى فرهنكى تبه يحيى بــــ دوره

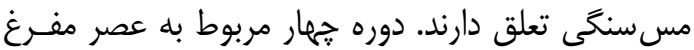

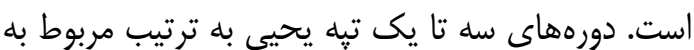

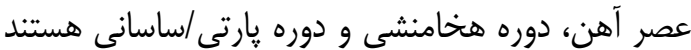

تاريخهاى قديمى كالدول براى ابليس بوده است. كالدول

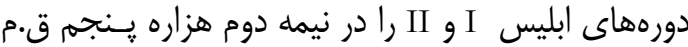

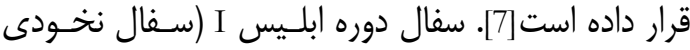
منقوش) در دورههاى VC و VB تِّه يحيسى رواج داشـته است و سفال دوره ابليس II (قرمز منقوش)، سفال رايـج دوره يحيى VA بوده اسـت. شـباهت معمـارى و سـفال

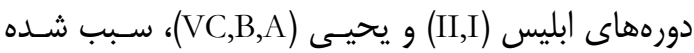

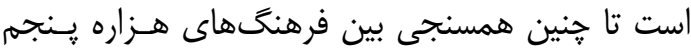
ق.م اين دو محوطه صورت بحيرد. بهطـور كلى، ازلحـاظ

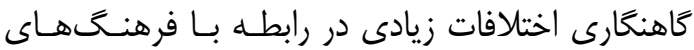
هزاره پنجم ق.م جنوب شرق ايران وجود دارد. همجنين

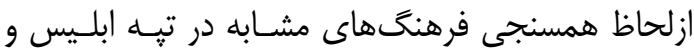

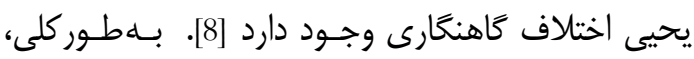

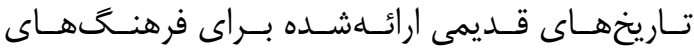
ييشازتاريخ جنوب شرق ايران كه از زمان آنها نيمقرن

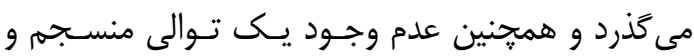
دقيق از فرهنخَهاى منطقه، لزوم بـازنخرى كاهنحـارى جنوب شرق ايران را دوجندان مى كند. 
محوطه لازم بود؛ به اين صورت كه عرصهى تبه بهطهور

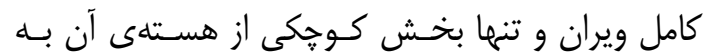

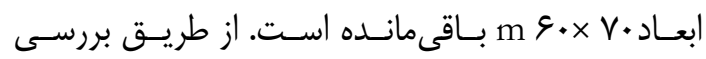

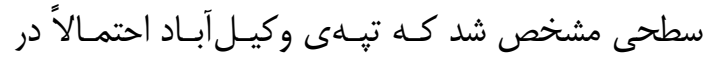
دورمى يحيى V استقرار داشته و با توجه به ديوارمى تبه

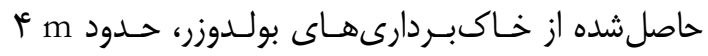
نهشتهى فرهنتحى مـرتبط بــا ايـن دوره داشـتيم. تنهــا

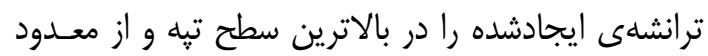
جاهاى سالم باقىمانده در سطح انتخـاب كـرديم. روش

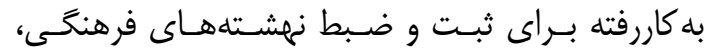

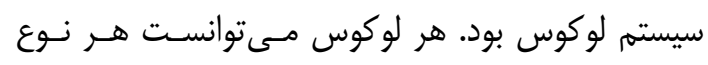

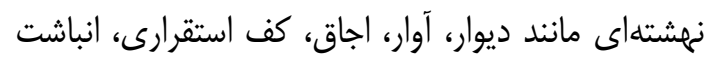

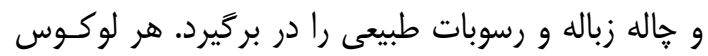

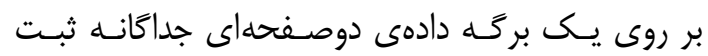

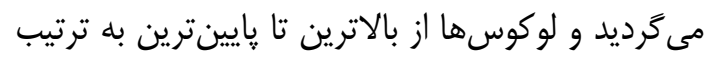

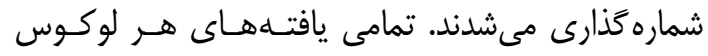

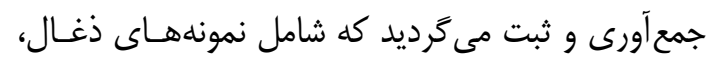

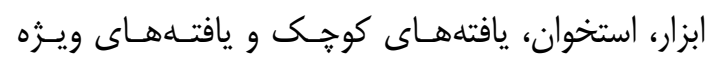

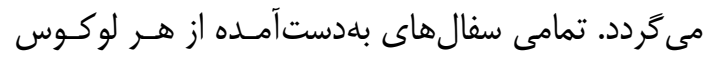

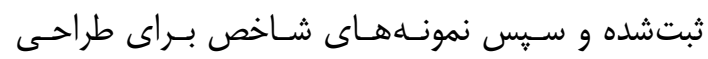
انتخاب مى كرديد. درواقع، اصلىترين هدف از كاوش لايهنغارى تيه

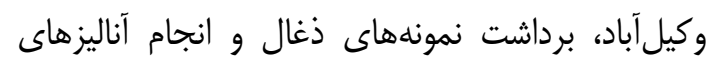

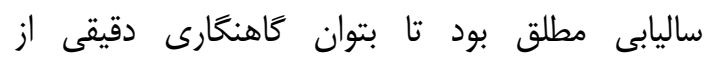
فرهنَّهاى ييشازتاريخ جنوب استان كرمان ارائه كرد. جهت نيل به اين مقصود، يك كاوش كنترلشده بر بر روى

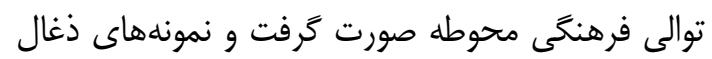
از لايههاى متفاوت آن برداشت كردد و و از از اين ميان

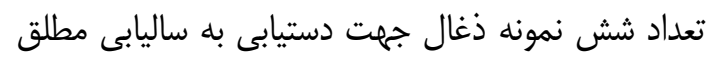

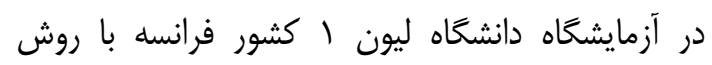
طيفسنج جرمى شتابدهنده مورد آناليز قرار كرفت كه جلوتر به شرح آن يرداختهشده است.

\section{س-1 ا. مواد و روشها} در كاوش تبه وكيل آباد شهرستان ارزوييه عاوه بلاه بر ارائـه يك كاهنكارى نسبى بر اساس روش مقايسهاى سـفال،

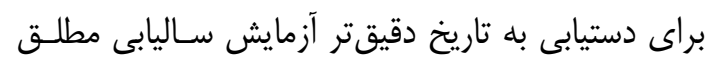

[1]. به نظر مىرسد تِه يحيى بـهـ مـدت بـيش از شـش

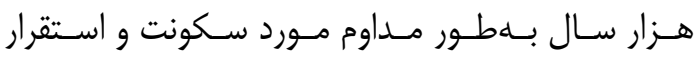

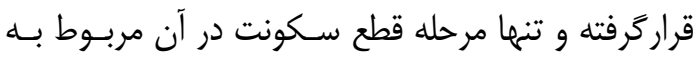

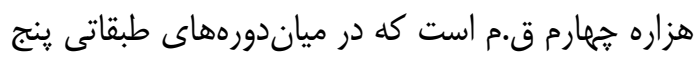

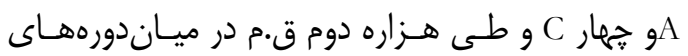

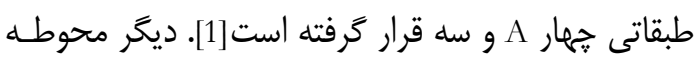
كاوش شده ييشازتاريخى جنوبشرق ايران تـل ابلـيس فيس

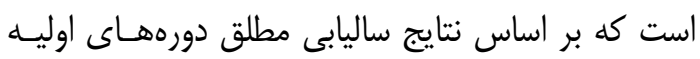

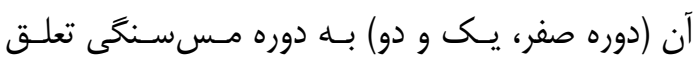

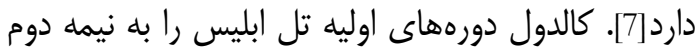

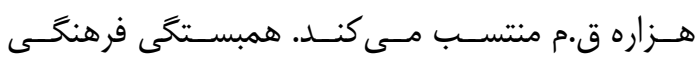

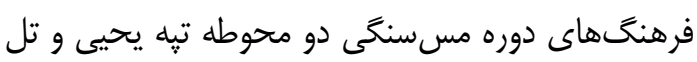

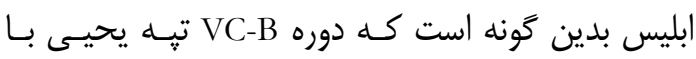

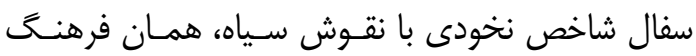

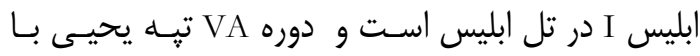

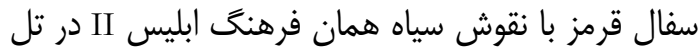

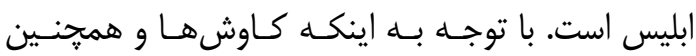

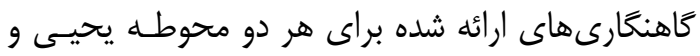

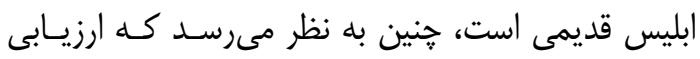

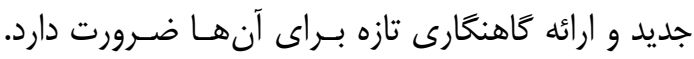

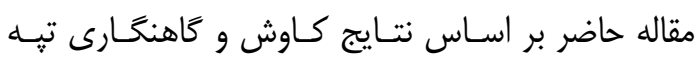
وكيل آباد به اين امر مىيردازد.

\section{س. اهداف و روششناسى كاوش تيه وكيلآباد}

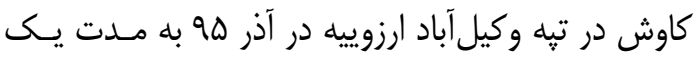

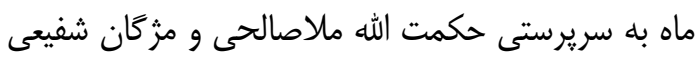
انجام شد. اهداف اصلى كـاوش تيـهـ وكيـل آبـاد عبـارت

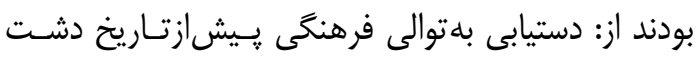

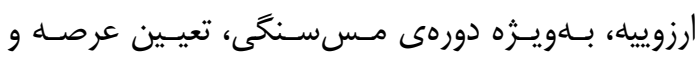

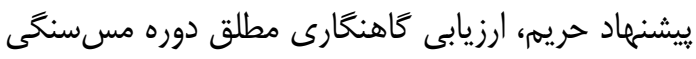

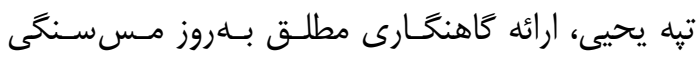

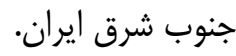
ييشتر از انجام اين يروزم، اين محوطه طى بروسى إنى

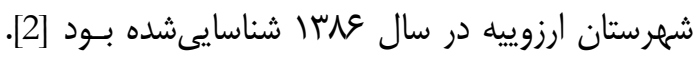

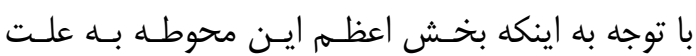
فعاليت عمرانى و كشاورزى از بين رفته است؛ انجام يكى إنى

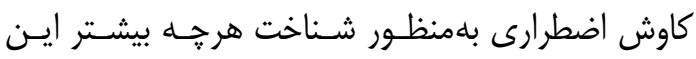

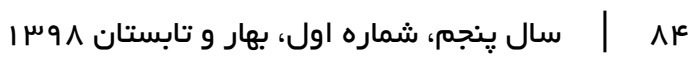


توسط لابراتوار دانشخاه ليون ا به سال تقـويمى تبـديل

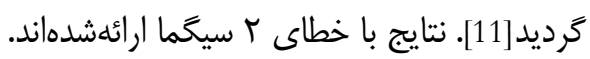

\section{f أ. كاوش لايهنگًارى و كَمانهزنى بلمنظور تعيين عرصه تبه وكيلآباد}

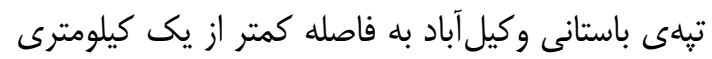

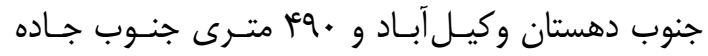

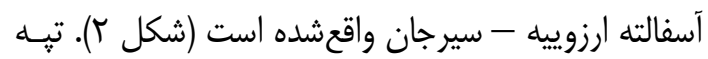
يادشده در دشت آبرفتى به نسبت هموارى قراركرفته كه شيب ملايم آن از شمال به جنوب است. رود فصلى خبر آنس

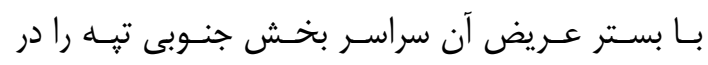

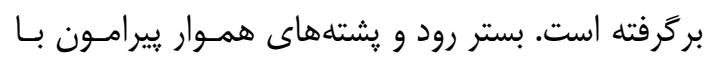
بوتههاى يراكنده رسم (Resm) و درختان كنـار (Konar)

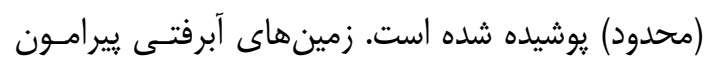

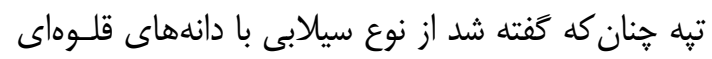
ريزودرشت شن و ماسه يوشيده شده است و تيه باستانى

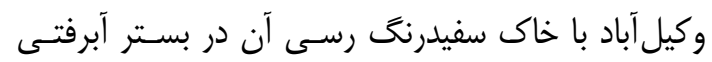
خودنمايیى مى كند. ارتفاع تبه از سطح زمينهاى يِيرامون 9 متر اسـتـ.

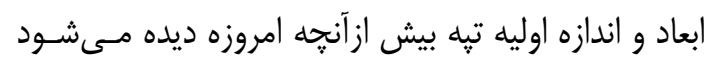

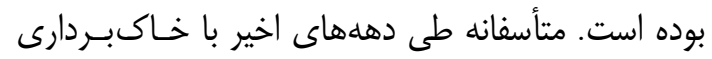

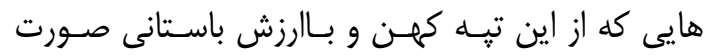

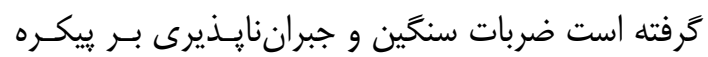

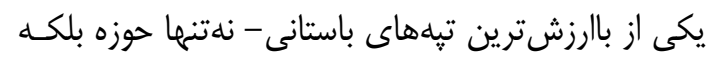

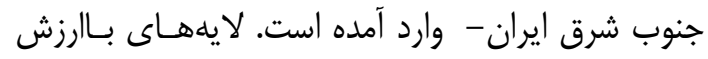

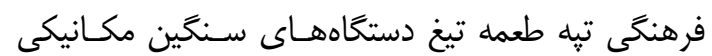

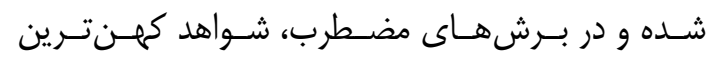
استقرارها ديده مى شود كه از بين رفتهاند. در اين غـارت

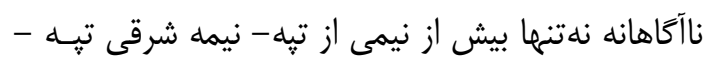

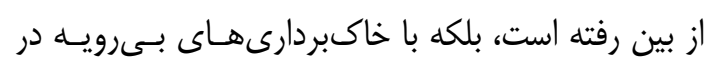

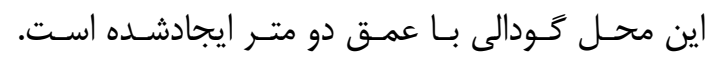

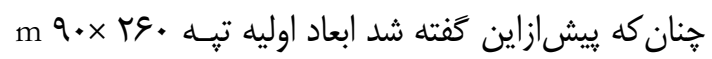

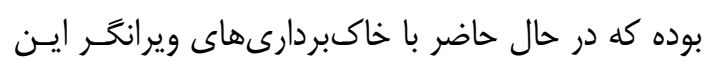

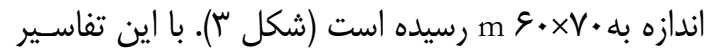

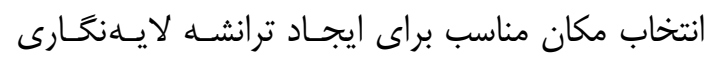

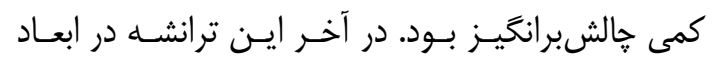

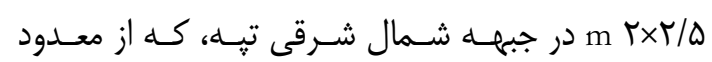

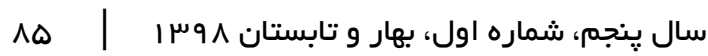

نيز صورت كرفت. در ايـن راسـتا تعـداد و نمونسه آنـاليز

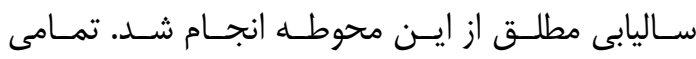

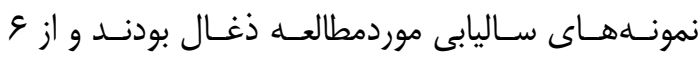
لوكوس مختلف جمع آورى گرديد. اندازه نمونهها متفاوت دونات

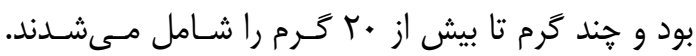

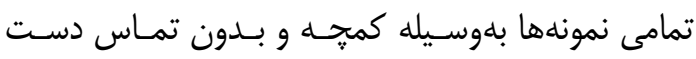

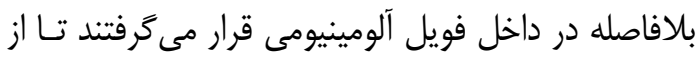

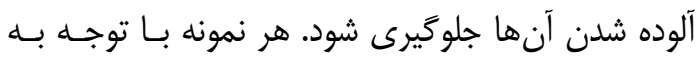

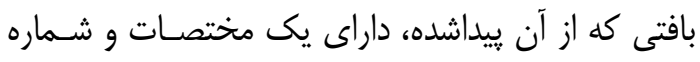

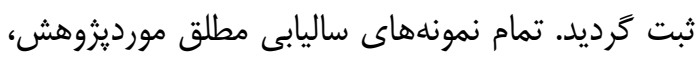

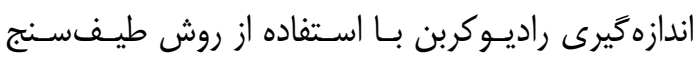
جرمى شتابدهنـده (Accelerator Mass Spectrometer)

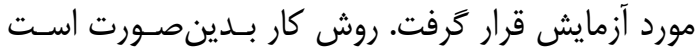

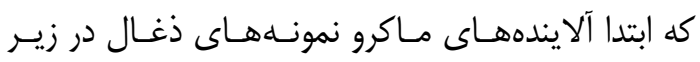
ميكروسكوٍ نورى حذف و بخش انتخابشده نمونسهـــا

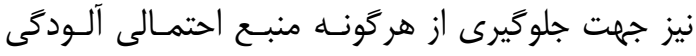

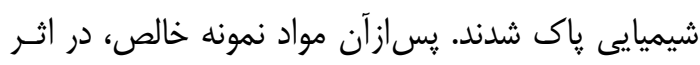

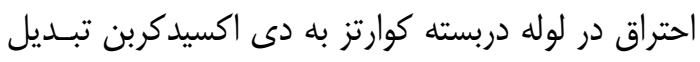

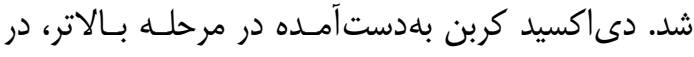

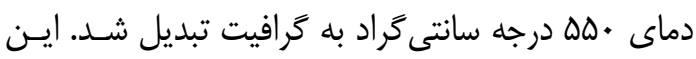

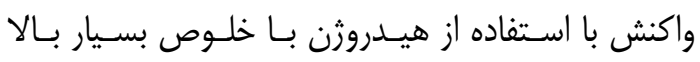

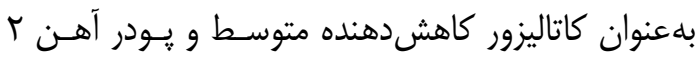

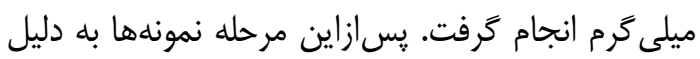

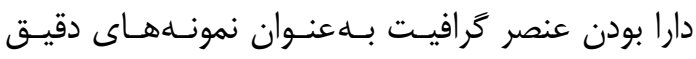

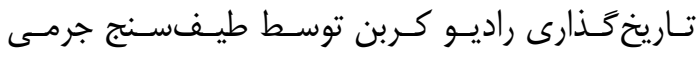
شتابدهنده مورداستفاده قرار كَرفتند. غلظت رادئ راديو كربن در طيفسنج جرمى شتابدهنده با مقايسه مقادير كـربن

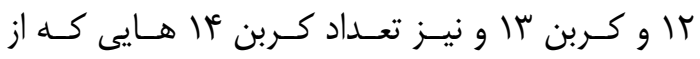

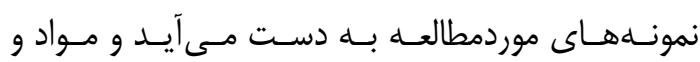

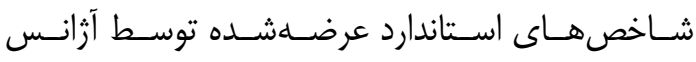
بينالملى انرزى اتمى و موسسه ملى استاندارد و فناورى

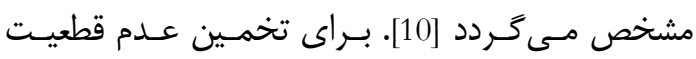

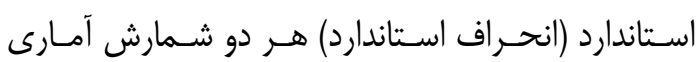

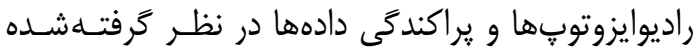

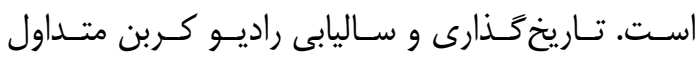

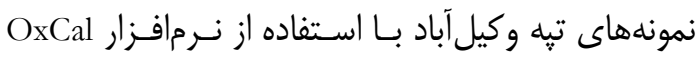
نسخه 3.2، بر اساس آخرين و بلهروزترين دادههاى جوى بـادي 


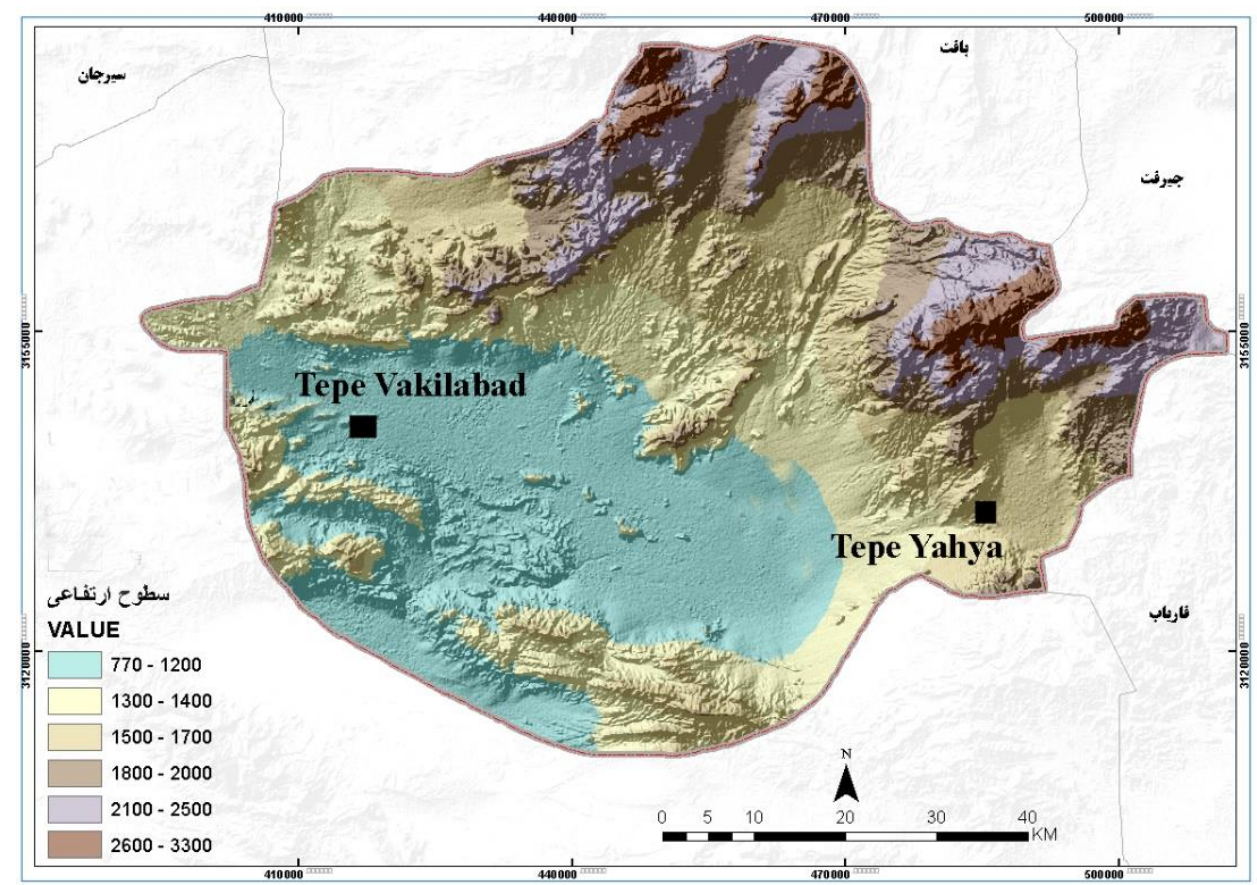

شكل r: موقعيت تِّه وكيلآباد نسبت به تِه يحيى در شهرستان ارزوييه

Fig.2. The location of Tepe Vakilabad compared to tepe Yahya

درنتيجه كاوش، الا لوكوس شناسايى شد كه در عمق ب

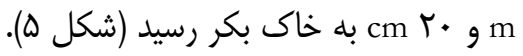

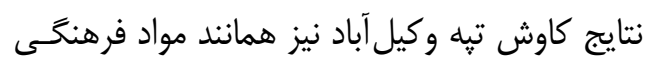

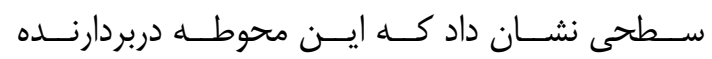
استقرارهايى از هزاره ينجم ق.م بوده است. از اين ترانشه دانه

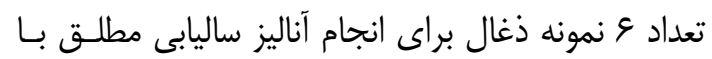
روش طيفسنج جرمى شتابدهنده تهييه كرديد. شـرايط

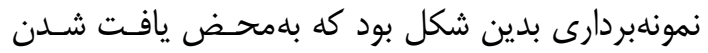

بخشهاى دستنخورده تِه و مرتفعترين قسمت بود، باز شد (شكل ع). در اين بخش، تبه بـهاوواسـطه برشى كـهـ توسط بولدوزر در آن ايجادشده است داراى شـيب بسـيار

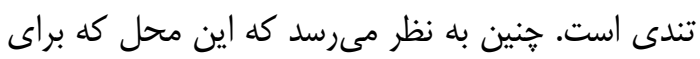
ايجاد ترانشه انتخابشده است يِيش از تخريب محوطهـ،

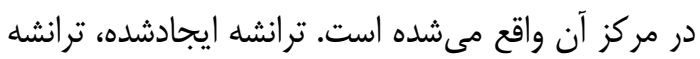

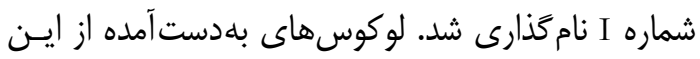

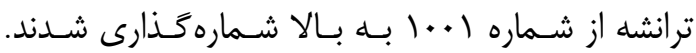

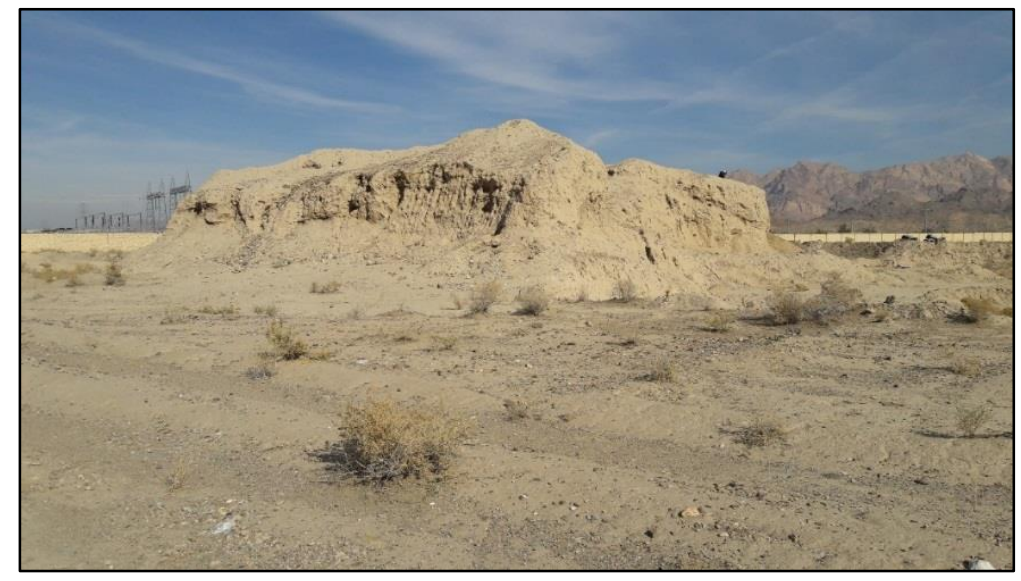

شكل "ا: تيه وكيل آباد و منظر كاه طبيعى بيرامونش (ديد از شرق)

Fig.3. Tepe Vakilabad and its natural landscape (View from East) 


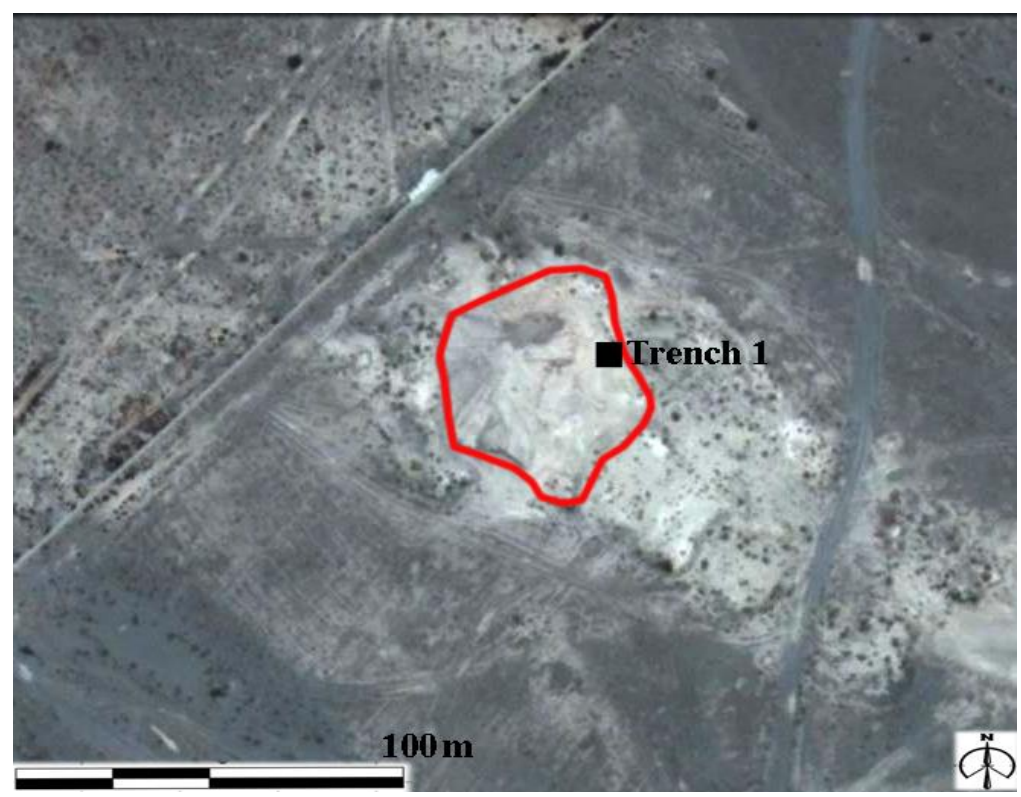

شكل t:تصوير ماهوارماى تبه وكيل آباد و محل ترانشه (كوكل ارث)

Fig4. The satellite image of tepe Vakilabad and the location of the trench I on google earth

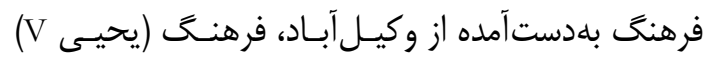
است. طبق كاوش ترانشه ايجادشده در تِّهـ وكيـل آبـاد،

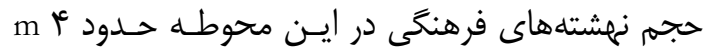

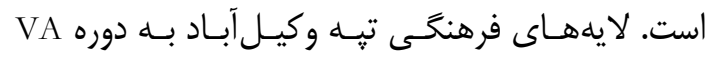

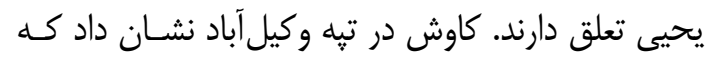
اين محوطه بر روى يك بستر طبيعى شكل

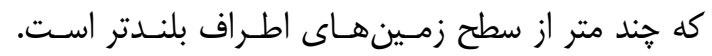

عمليات كاوش متوقف مى گردد و با استفاده از كمجـهـ و

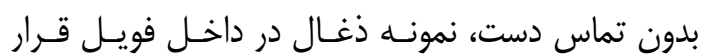
مى كَرفت و سيس مختصات محل كشف آن در ترانشـهـ

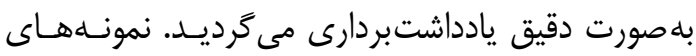

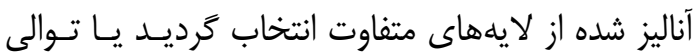

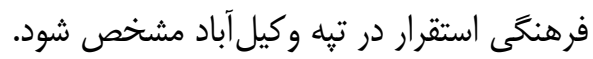
بر اساس كاهنغارى نسبى مبتنى بر مقايسه سفالى،

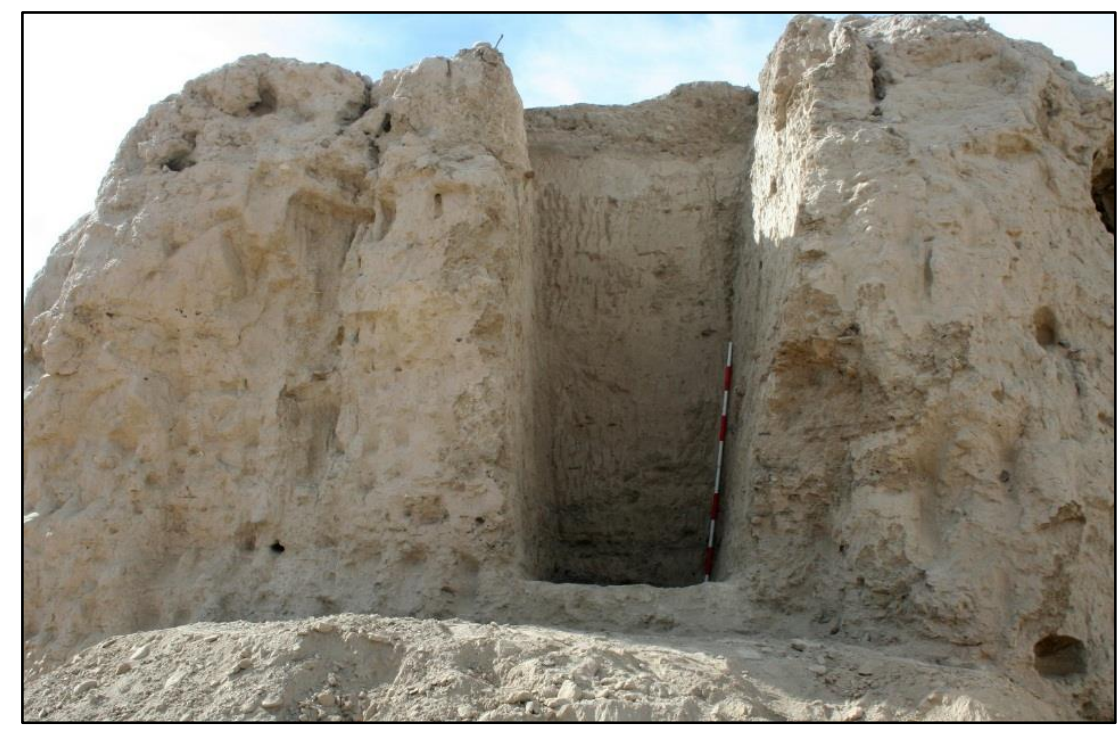

شكل ه: ترانشه لايهنكارى تيه وكيل آباد

Fig.5. The stratigraphic trench of Tepe Vakilabad

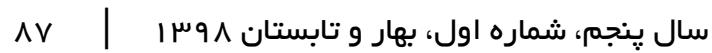




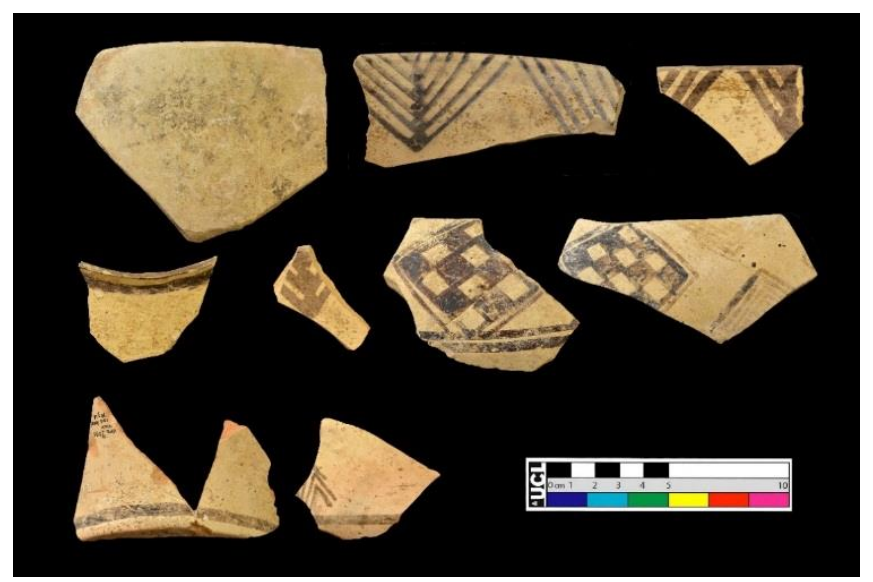

شكل V: نمونه سفال هاى فرهنگ يحيى V از تيه وكيل آباد Fig.7. Ceramics of Yahya V culture recovered from Tepe Vakilabad

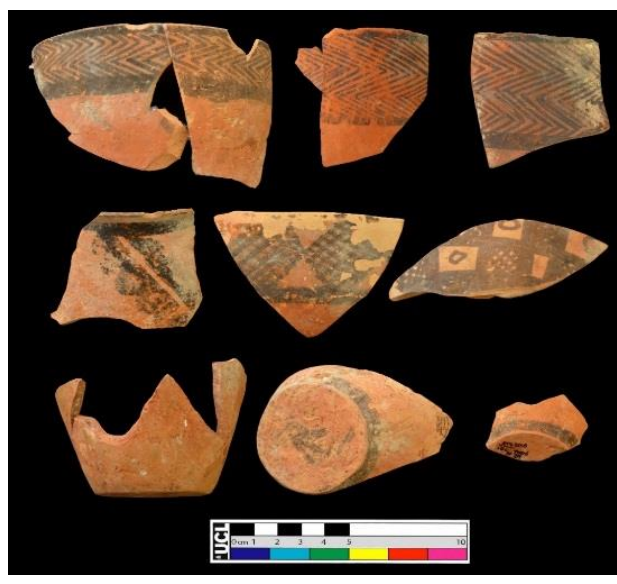

شكل و. نمونه سفال هاى فرهنگ يحيى V از تبه وكيل آباد Fig.6. Ceramics of Yahya V culture recovered from Tepe Vakilabad

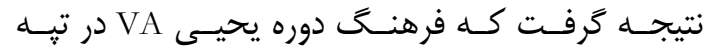
وكيل آباد مستقر بوده است هر خند سنت سفالى دوره قبلى فيلى

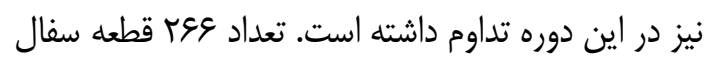

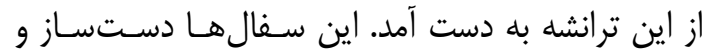
داراى تزييناتى جون خطوط مستقيه، هاشور، طـرحهـاى

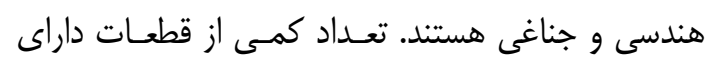
نقش روى سطح داخلى هسـتند. يـك نمونـه سـفال بــا

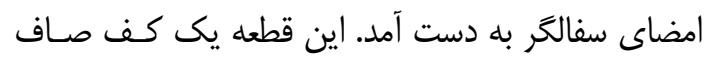

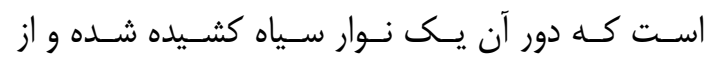

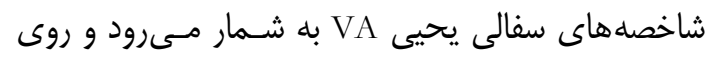
سطح خارجى كف امضاى سفالكر ديده مىشود.

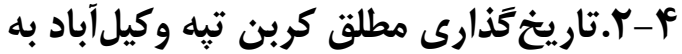 روش AMS-14C}

كاوش در تيه وكيل آباد منجر به شناسايى دو دوره سـفالى

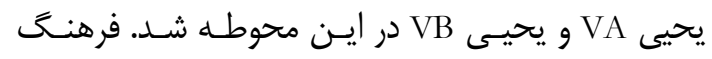
سفالى غالب اين محوطه يحيى VA است و سفال يحيسى

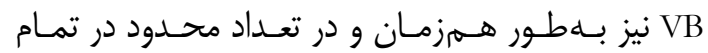
لايههاى داراى سفال اين محوطه به جشم مى خورد. نتايج

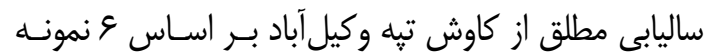

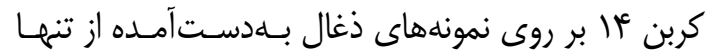
ترانشه كاوش شده به روش طيفسنج جرمى شتابدهنده

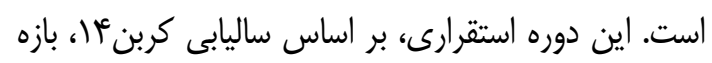

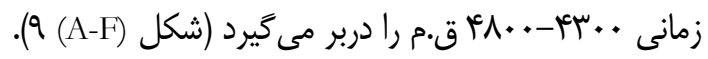

ازاينرو تعيين عرصه اين تيه كار جندان پيیجيدهاى نبود.

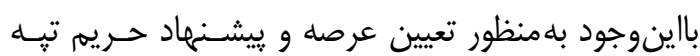

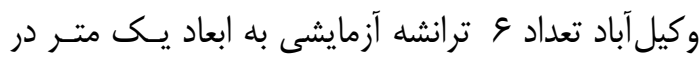

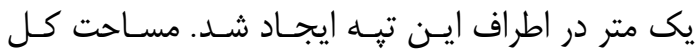

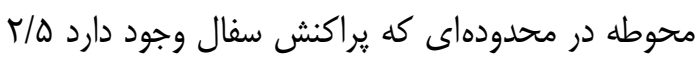

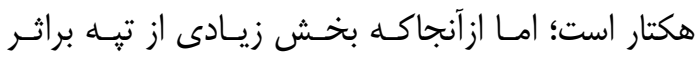

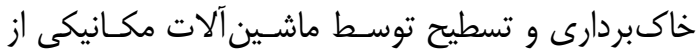

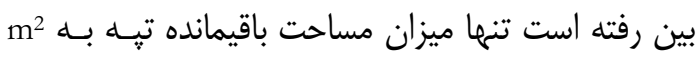

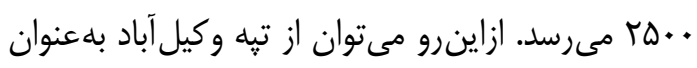
يك محوطه روستايى كوجى در دشت ارزوييه نام برد.

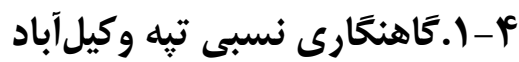

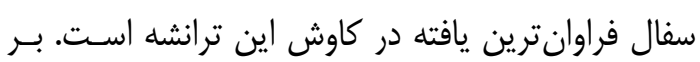

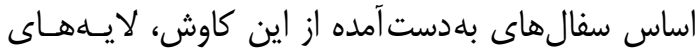
فرهنكى تيه وكيل آباد به دوره ينجمم يحيى تعلـق دارنسلد.

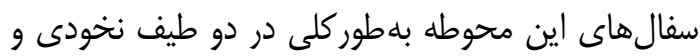

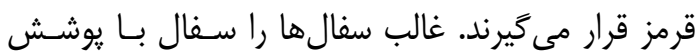

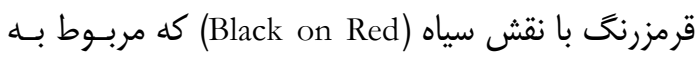
دوره VA يحيى است تشـكيل مسىدهـــ (شـكلمرو وو). همجنين سفالهاى شاخص دوره VB يحيى يعنى سفال

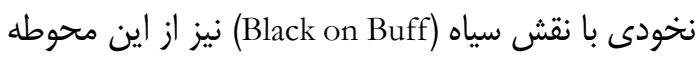

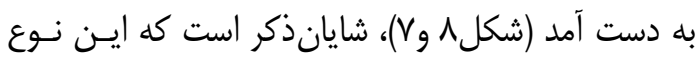
سفال ازلحاظ كميت نسبت به سفال قرمز، درصد كمى از كل سفالها را به خود اختصاص مى دهد. ازاينرو مىتوان 


\begin{tabular}{|c|c|}
\hline سنجج & دو فصلنامه يُزوهه باستانسنجى \\
\hline
\end{tabular}
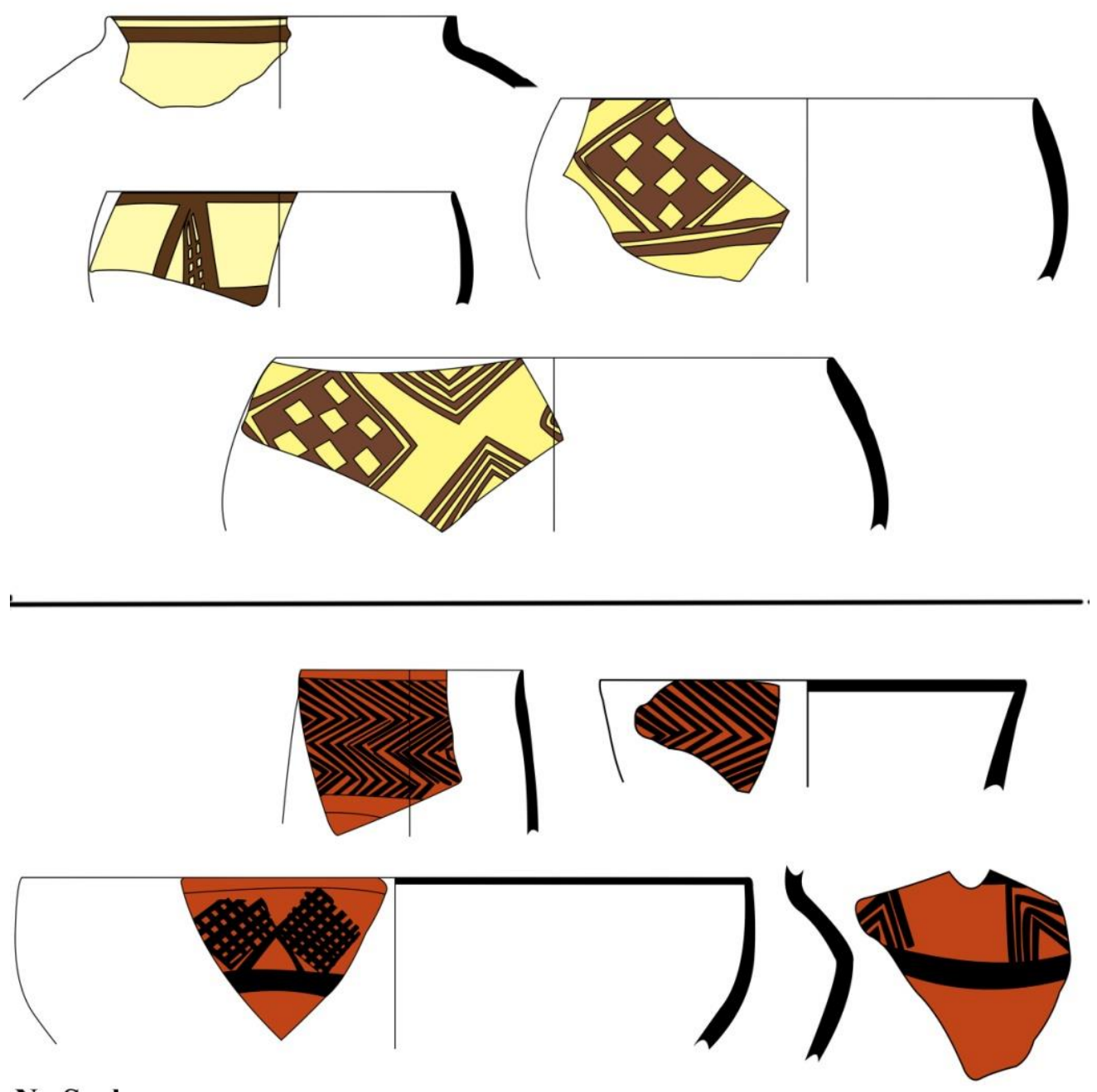

No Scale

شكل م: طرح سفال يحيى VC-B و يحيى VA از تبه وكيلآباد ارزوييه

Fig.8. Pottery drawing

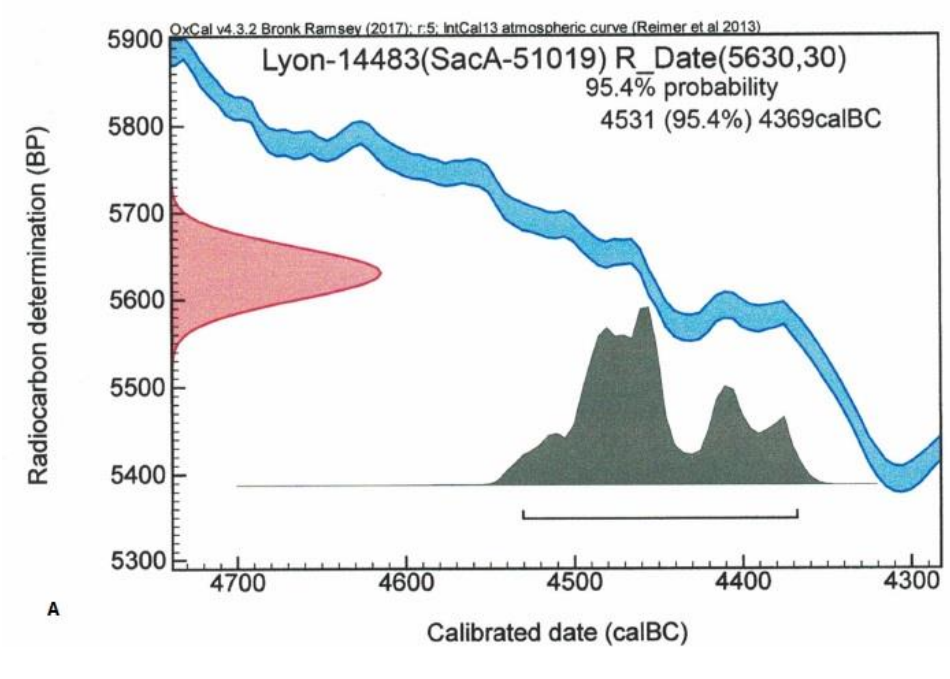

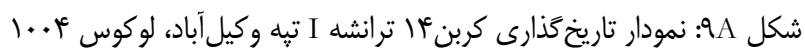

Fig. 9A: 14C date from Tepe Vakilabad, Trench I, Locus 1004

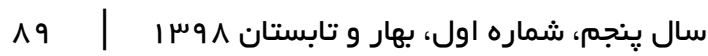




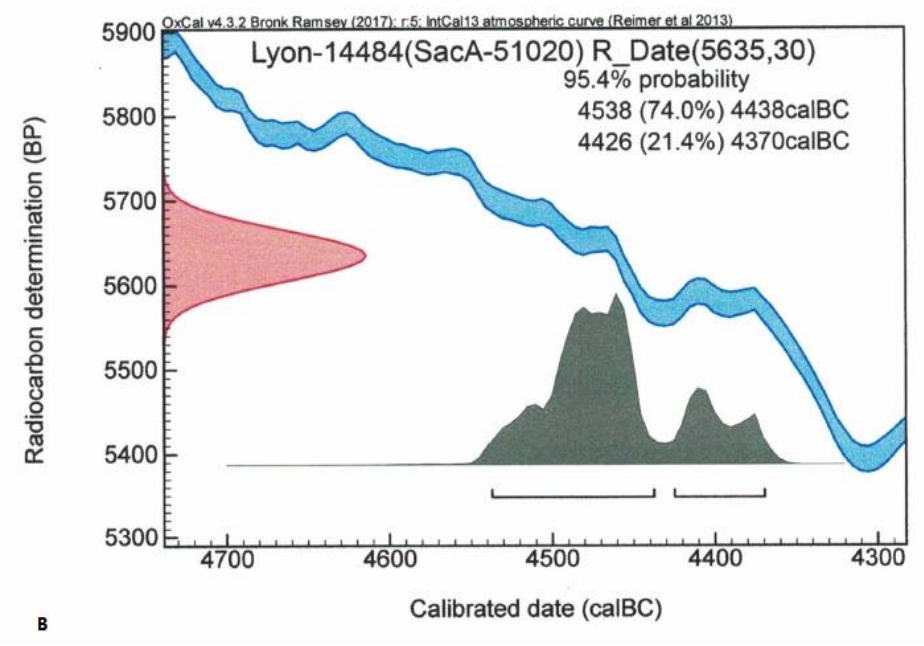

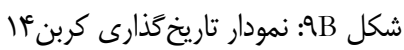

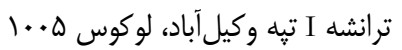
Fig. 9B: C14 date from Tepe Vakilabad, Trench I, Locus 1005

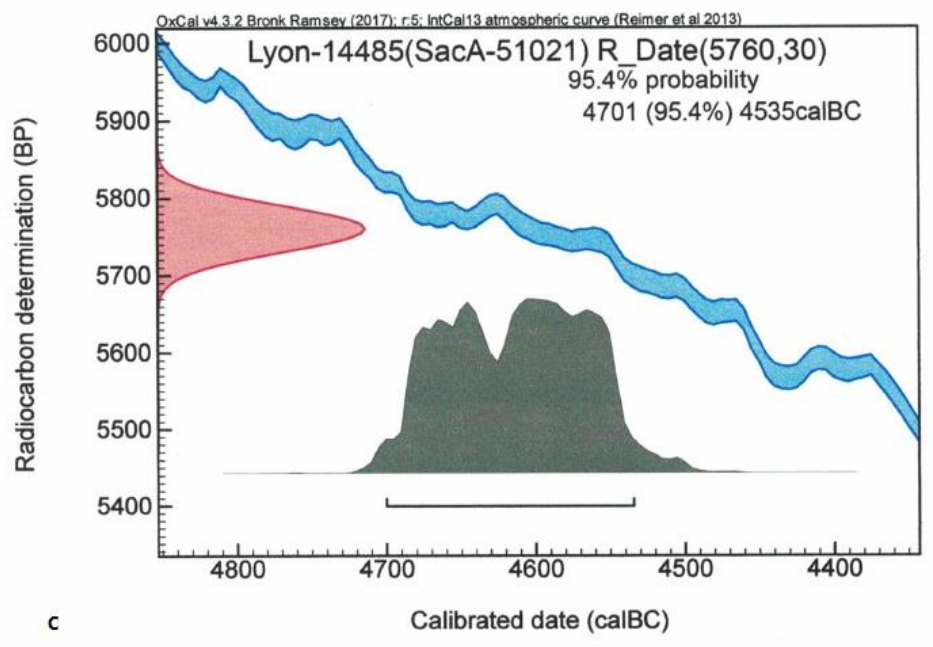

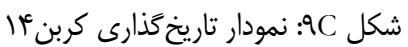
ترانشه I تبه وكيل آباد، لوكوس و Fig. 9C: C14 date from Tepe Vakilabad, Trench I, Locus 1006

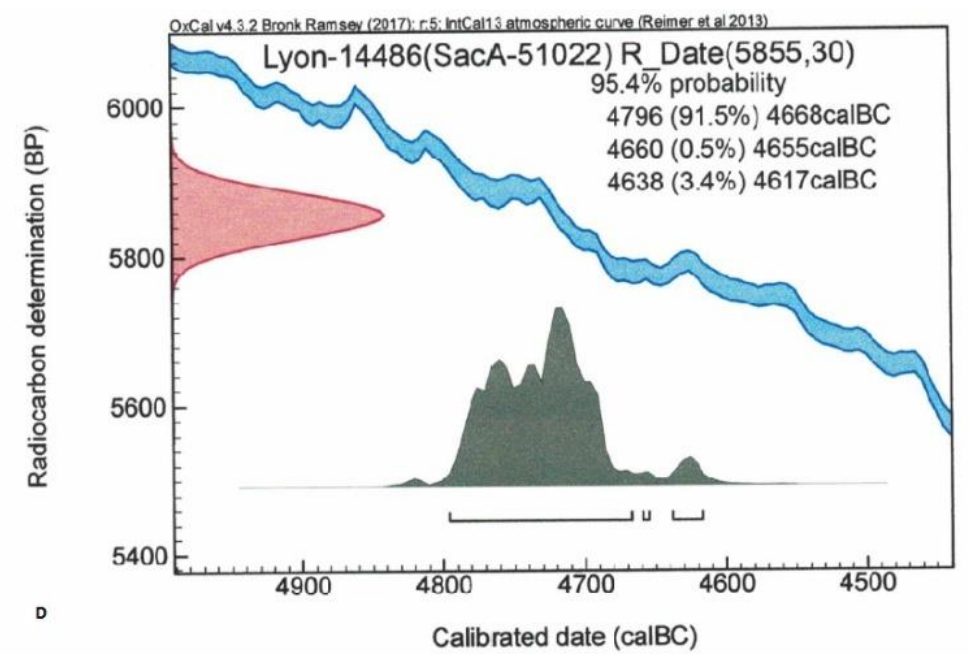

شكل Dq: نمودار تاريخ كذارى كربن ترانشه I تبه وكيل آباد، لوكوس Fig. 9D: C14 date from Tepe Vakilabad, Trench I, Locus 1009 


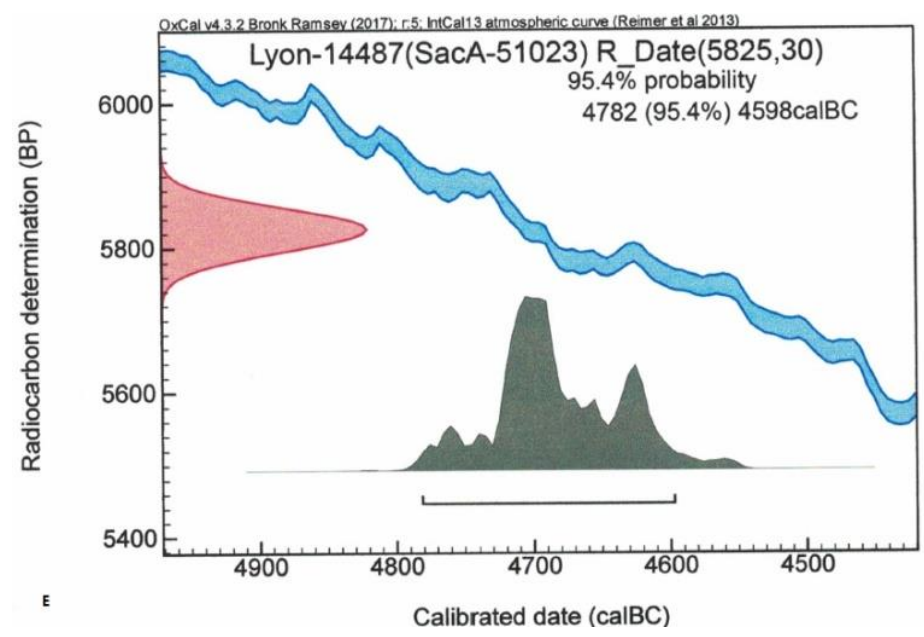

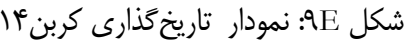

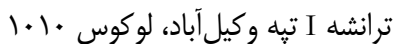

Fig. 9E: 14C date from Tepe

Vakilabad, Trench I, Locus 1010

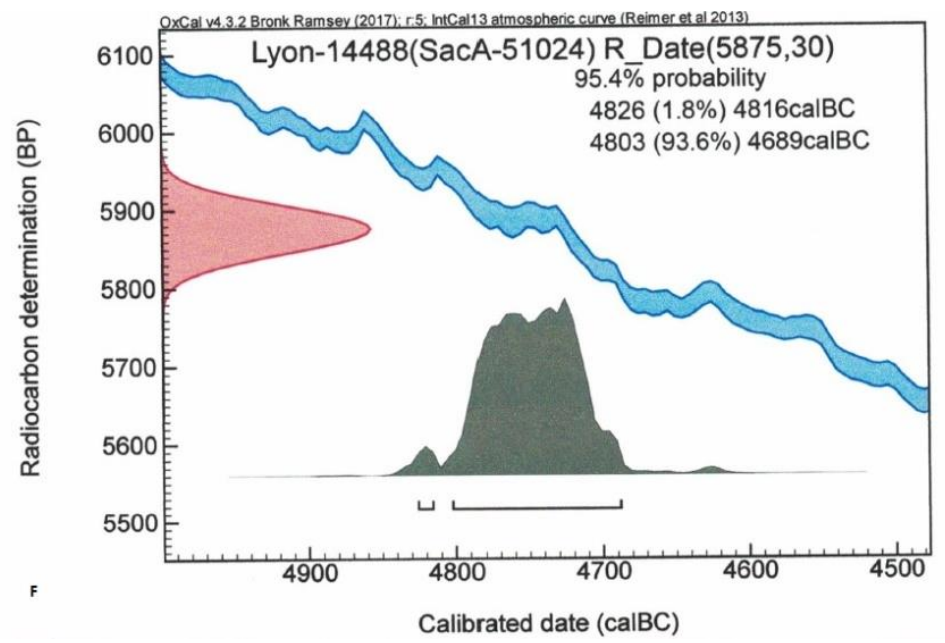

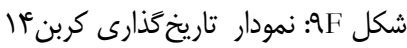

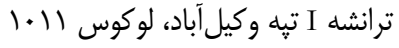

Fig. 9F: 14C date from Tepe Vakilabad, Trench I, Locus 1011

تاريخ بازسنجى شده براى دورههـاى اوليـهـ يحيسى ارائـه

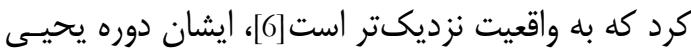

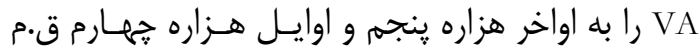
نسبت داد. يك نمونه تاريخ كذارى مطلق از تيه مرادآبـاد

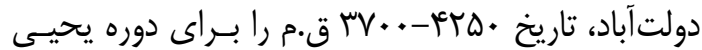

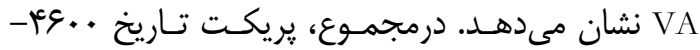

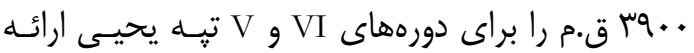

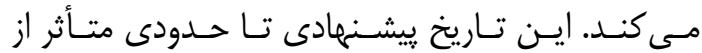
تاريخهاى قديمى كالدول براى ابليس بوده است. كالدول

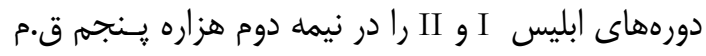

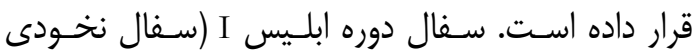
منقوش) در دورههاى VC و VB تِه يحيـى رواج داشـته

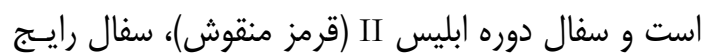
دوره يحيى VA بوده اسـت. شـباهت معمـارى و سـفال

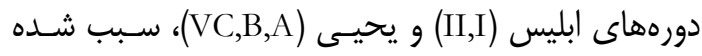

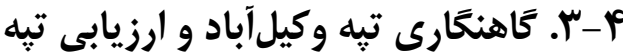
يحيى

با توجه به دادههاى سفالى تيه وكيـل آبـاد و كاهنـــارى نسبى و مقايسهاى اين تيه با تِه يحيى مىدانيهم كه اين محوطه در دوره يحيى VA استقرار داشـته اسـت. نتـايج آزمايش كربن ألا بر روى نمونههـاى ذغـال، اطلاعـات جديد و جالبى از اين دوره را در اختيـار مـا قـرار داد. بــر

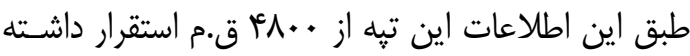
و حدود . ..ه سال نيز به حيات خود ادامه داده است. بر اساس نظر لمبرى كارلوفسـكى و تومـاس بيـل،

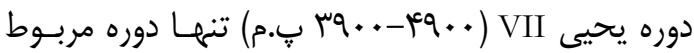

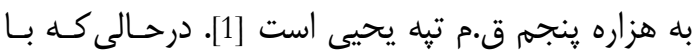
توجه به نتايج اين يزوهش اين بازه زمـانى دوره يحيسى

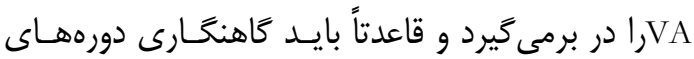

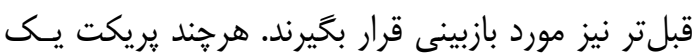




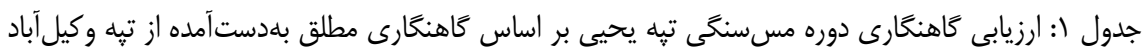
Table1: Revision of the chronology of the Chalcolithic period of Tepe Yahya based on Tepe Vakilabad excavations

\begin{tabular}{|c|c|c|c|}
\hline $\begin{array}{c}\text { Period } \\
\text { دوره }\end{array}$ & $\begin{array}{c}\text { Proposed Chronology of } \\
\text { Lamberg-Karlovsky and } \\
\text { Beale } \\
\text { كاريخ كذارى ويشنهادى }\end{array}$ & $\begin{array}{c}\text { Proposed } \\
\text { Chronology of } \\
\text { Prickett } \\
\text { تريخ كذارى ييشنهادى } \\
\text { تريكت }\end{array}$ & $\begin{array}{l}\text { Proposed Chronology } \\
\text { of Author } \\
\text { تاريخ كذارى يشيشنهادى }\end{array}$ \\
\hline$\overline{V C \& V B}$ & 3900-3300 BC & $\begin{array}{c}\text { Mid } 5^{\text {th }} \text { millennium } \\
\text { BC }\end{array}$ & 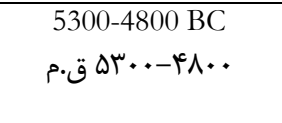 \\
\hline VA & & 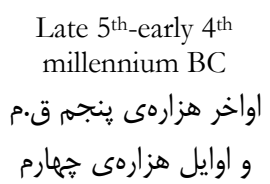 & 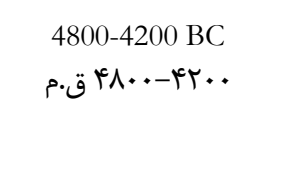 \\
\hline
\end{tabular}

كَاهنخًارى دورههـاى يحيـى وجـود دارد، قـديمى بـودن

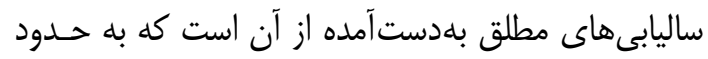

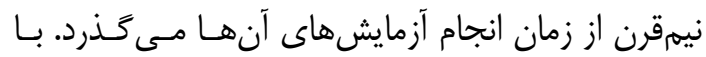

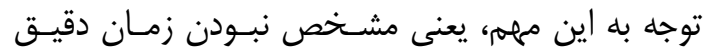

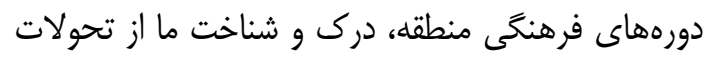
فرهنگى در بستر تاريخى خـود دقيـق نيسـت. ازايـنرو،

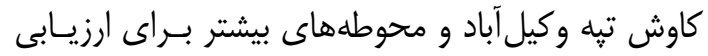

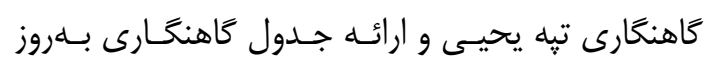

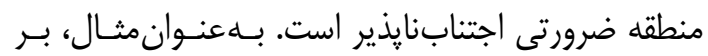
اساس تاريخ كذارى قديمى تِه يحيى، تـاريخ يِيشـنـهادى

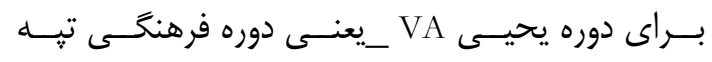

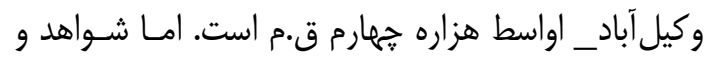

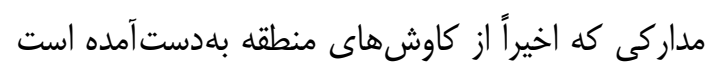

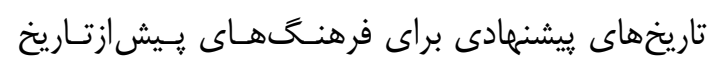
منطقه كرمان را با يرسش و ترديد مواجه كرده است[8].

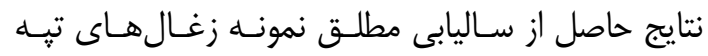

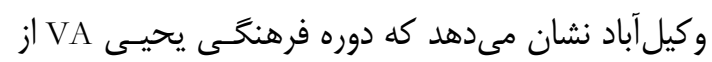
اوايل هزاره ينجمم پ.م شروع و تا اوايـل نيمـه دوم ايـن

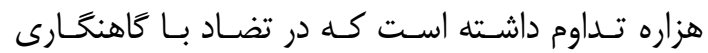

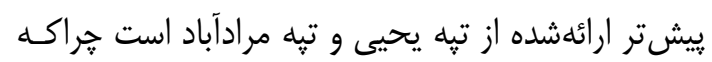

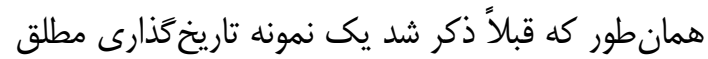

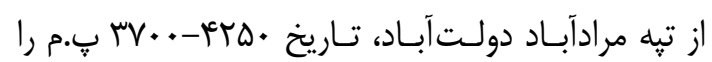
براى دوره يحيى VA نشان مىدهد و يريكت نيز تـاريخ

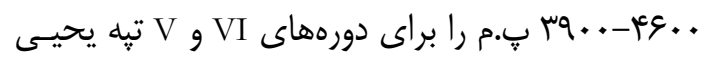

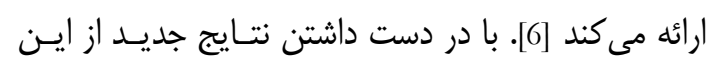

است تا جنين همسنجى بين فرهنَّهاى هـزاره يـنجمم

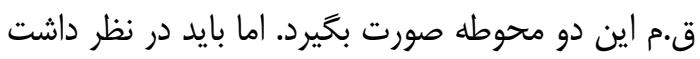

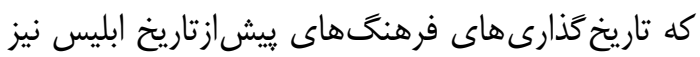

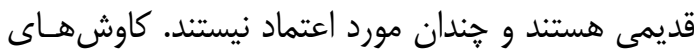

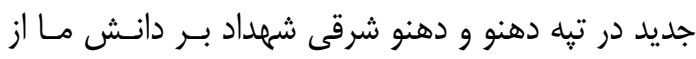

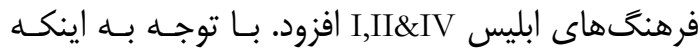

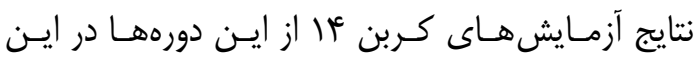

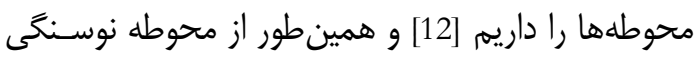

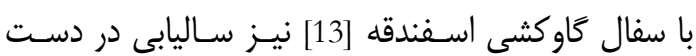

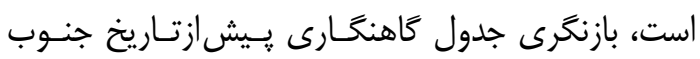

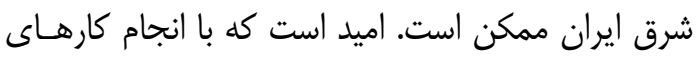

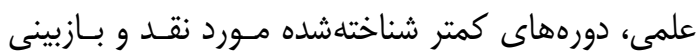

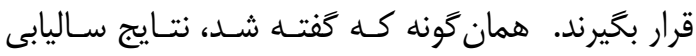

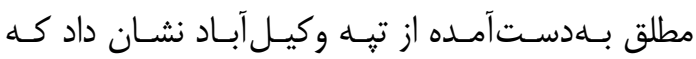

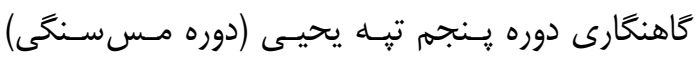

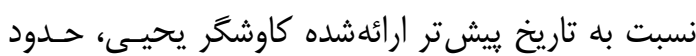
يك هزار سال به عقب بازمى گردد (جدول ()).

\section{(}

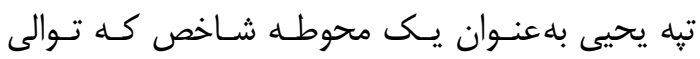

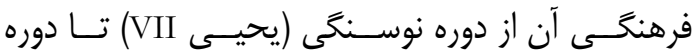

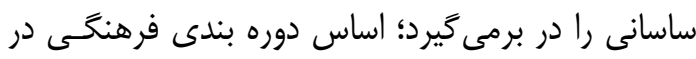
جنوب استان كرمان است. ساليابى مطلق بهدست آمده از كاوشهاى تيه يحيى مبناى زمـانى دورههـاى فرهنخَى

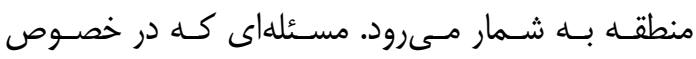


كاوش وكيل آباد زمينهاى را فراهم آورد تا بتوان بـا ارائسهـ تاريخ كذارى مطلق جديد از اين فرهنــ، بــا ارزيـابى و بازنخرى كاهنخارىهاى قديمى ارائهشده توسط لمبـرى كارلوفسكى براى دوره مسسنكى تيه يحيى ثرداخت. بـا

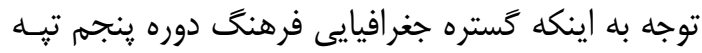

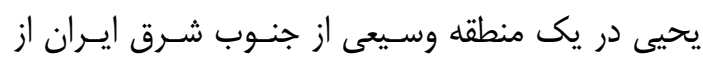

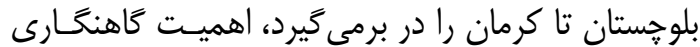

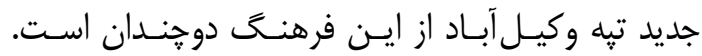

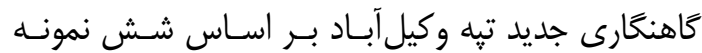

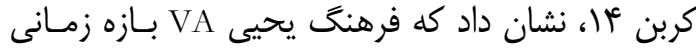

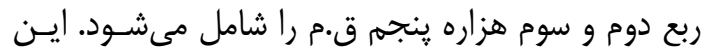

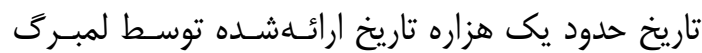

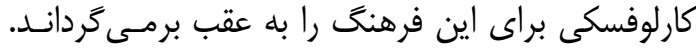

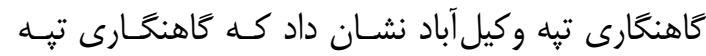

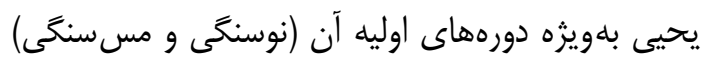
نيازمند يك بازنخرى اساسى است.

\section{سياسگَزارى}

از يزوهشكده باستانشناسى جهت صدور مجــوز كـاوش

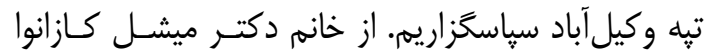

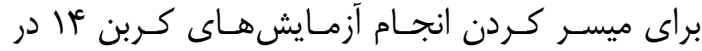

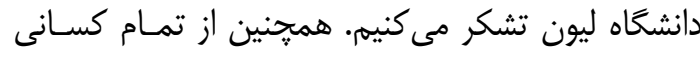
كه در كار ميدانى يروزه كاوش تبه وكيـل آبـاد مشـاركت داشتهاند و همرجنين آقاى عليدادى سليمانى كه ناظر اين يروزه بودند، كمال تشكر را داريم.

\section{References}

[1] Lamberg-Karlovsky CC, Beale TW, Adovasio J, Heskel D, Mckerrell H, Meadow Rh, Et Al. Excavations at Tepe Yahya, Iran, 1967-1975. The early periods. Am Sch Prehist Res Bull. 1986(36).

[2] Soleimani N, Report of the archaeological survey of Orzu'iyeeh plain, Cultural Heritage, Handicrafts and Tourism Organization of Kerman Iran, 2008. [In Persian].

$$
\begin{aligned}
& \text { [سليمانى نادر. كزارش بررسى باستانشناسـى دشــ }
\end{aligned}
$$

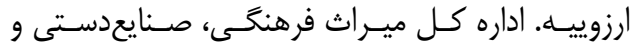

$$
\begin{aligned}
& \text { كردشخَّى استان كرمان، ايران، عربـ|]. }
\end{aligned}
$$

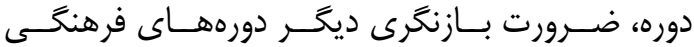

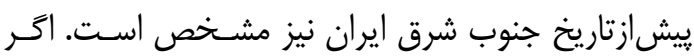

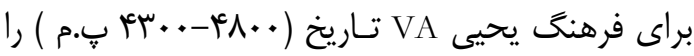
در نظر بحيريه، نظريه لمبرى كارلوفسكى مبنى بر اينكه

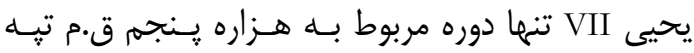

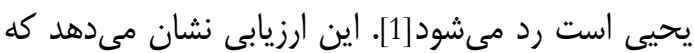

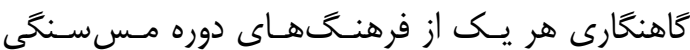

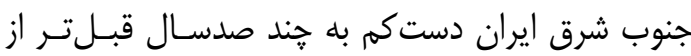
تاريخى كه ييشتر براى آنها ذكر كردهانده، بازمى كردند.

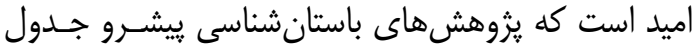
كاهنغارى بلهروز و دقيقى از جنوب شرق ايران ارائه كند.

\section{ه. نتيجل كَيرى}

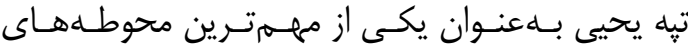
ييشازتاريخى جنوب شرق ايران به شمار مىرود؛ جراكه

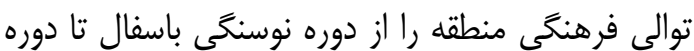

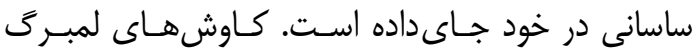
كارلوفسكى در تيه يحيى در نيهقرن ييش منجر به ارائه

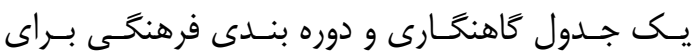
منطقه جنوب شرق گرديد كه كماكان نيـز مورداسـتفاده قرار مى گيرد. بر اساس اين جدول كاهنغارى، دورههـاى

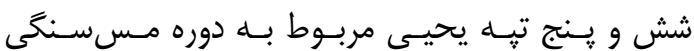
مىباشند. كاوش لايهنغارى تيه وكيل آباد در غرب دشت دري

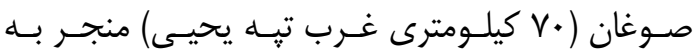
شناسايى فرهنَ دوره يحيى ينج در اين محوطه كَردد.

[3] Vidale M, Desset F. Mahtoutabad I (Konar Sandal South, Jiroft): Preliminary evidence of occupation of a Halil Rud site in the early fourth millennium BC. Ancient Iran and Its Neighbours. Local developments and long-range interactions in the fourth millennium BC. 2013:23352.

[4] Alidadi Soleimani, N, Shafiee, M, Eskandari, N, Molasalehi, H, 2016. Khaje Askar.A fourth millennium BC cemetery in Bam, southeastern Iran, Iranica Antiqua, Vol. LI.

[5] Garazhian O, Rahmati M. Period I of Tal e Atashi: Pre-pottery neolithic culture and 
architecture in the landscape of SE

Iran.Pazhohesh-ha-ye Bastanshenasi Iran 3AD; 2012:111-48. [in Persian].

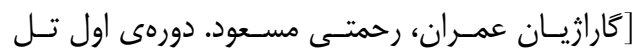

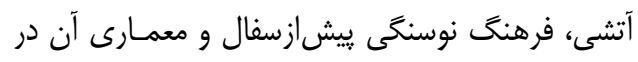

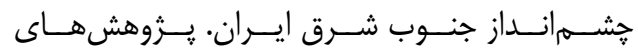

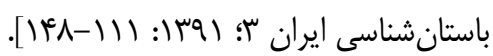

[6] Prickett M. Settlement during the early periods. Excav Tepe Yahya, Iran 1967;1975:215-46.

[7] Caldwell JR. Investigations at Tal-i-Iblis (Illinois state museum preliminary reports No. 9. Springf Illinois State Museum Soc 1967.

[8]Eskandari N. A Reappraisal of the Chronology of the Chalcolithic Period in SE Iran: Absolute and Relative Chronology of Tepe Dehno and Tepe East Dehno, Shahdad. JRA. 2018; 4 (1) :23-35 [In Persian].

[اسكندرى نصير. ارزيابى گاهنگًارى دوره مسسسـنـى

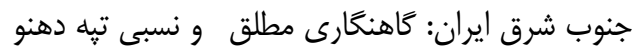

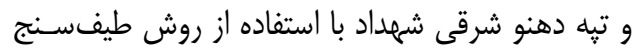

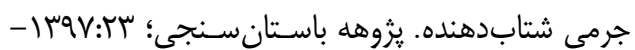

[9] Stein, S.A. Archaeological Reconnissances in North-Western India and South Eastern Iran, London. 1937

[10] Abedi A. Absolute (14C AMS) and Relative Chronology of Dava Göz Khoy; New Evidence of Transitional Chalcolithic, Dalma and Pisdeli Cultures in NW IRAN. Journal of Research on Archaeometry. 2016; 2(1):39-54.[In persian]

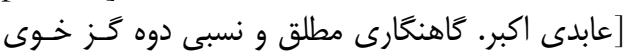

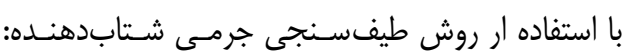

شواهدى از دوران مس و سنگ انتقالى، دالما و ييزدلى.

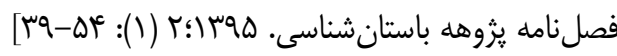

[11] Reimer PJ, Baillie MGL, Bard E, Bayliss A, Beck JW, Blackwell PG, et al. Intcal09 and marine 09 radiocarbon age calibration curves, 0-50,000 years cal BP. Radiocarbon 2009;51:1111-50.

[12] Eskandari N. 14th season of Dasht-e Lut project: Results of excavations at Tepe Dehno and east Dehno. In: Hessari M, editor. Pap. Honor Mir-Abedin Kaboli. Tehran: Research institute of cultural heritage \& tourism; 2017: 73-94. [In Persian].

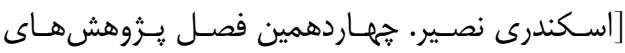

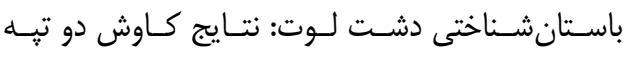

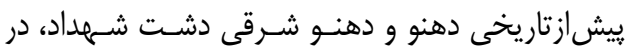

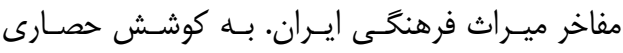

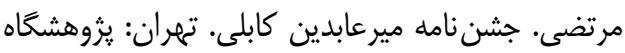

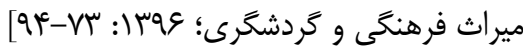

[13] Alidadi Soleimani N. Journal of Research on Archaeometry, The re-evaluation of Kerman Neolithic chronology based on the excavation of Tepe Gav Koshi Esfandagheh- Jiroft. 2018; 4(2): 61-79. [In Persian].

$$
\begin{aligned}
& \text { [عليدادى سـليمانى، ارزيـابى مجــد كَاهنَــارى دوره }
\end{aligned}
$$

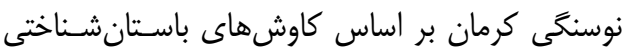

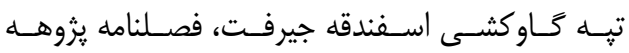

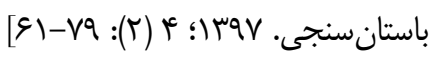

